Pamiętnik Literacki 2017, 4, s. 61-85
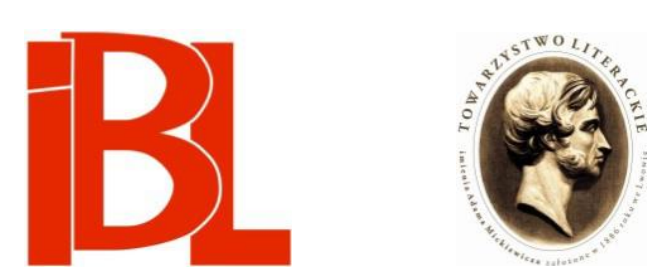

\title{
Dwuznaczność eksperymentu. O kategorii „odwróconego sacrum" w dyskursie krytycznym Jana Błońskiego
}

Małgorzata Szumna 
Pamiętnik Literacki CVIII, 2017, z. 4, PL ISSN 0031-0514

DOI: $10.18318 / \mathrm{pl} .2017 .4 .5$

MAŁGORZATA SZUMNA Uniwersytet Jagielloński, Kraków

\title{
DWUZNACZNOŚĆ EKSPERYMENTU O KATEGORII „ODWRÓCONEGO SACRUM" W DYSKURSIE KRYTYCZNYM JANA BŁOŃSKIEGO*
}

\author{
Błoński: W istocie jednak wszyscy - katolicy i niekatolicy - \\ chcemy być zbawieni. \\ Puzyna: Ja nie. Czy to czasem nie podważy twojej tezy? \\ Błoń ski: Wszyscy jesteśmy istotami metafizycznymi. Ty też. \\ Socjolog Czerwiński też. \\ Turowicz: A Kotarbiński? \\ C zerwińs ki: Też, i to w wysokim stopniu. \\ Puzyna: No, to stwierdzenie jest w stanie mnie załamać ${ }^{1}$.
}

\section{„Bluźniercy” i „wariaci”}

Błoński debiutował kilkakrotnie. Nie w rozumieniu rzeczywistego debiutu - ten mógł być, oczywiście, tylko jeden i taki też był: na łamach prasy pierwsze publikacje tego autora ukazały się w 1949 roku. Figura „wiecznego debiutanta” - by użyć tu określenia Janusza Margańskiego, zastosowanego przez niego w odniesieniu do Witolda Gombrowicza ${ }^{2}$ - dobrze jednak przystaje do Błońskiego. Za powtórny jego debiut wolno więc, jak sądzę, uznać Zmianę warty, za kolejny - obszerną książkę o Sępie Szarzyńskim; za następny - Romans z tekstem; za ostatni wreszcie (ale czy naprawdę?) - Kilka myśli co nie nowe. Za każdym razem Błoński jakby zaczynał się raz jeszcze: i choć można - patrzac z zewnątrz po latach - zaobserwować pewną logikę wynikania, prześledzić drogę koncepcji, to w autokomentarzu eseisty dotyczącym działalności krytycznej na plan pierwszy wysuwają się kategorie dużo mocniej naznaczone radykalizmem, podważające porządek koncyliacji, tak często stosowany w odniesieniu do tego twórcy; każdy kolejny początek wymaga bowiem

* Artykuł został przygotowany w ramach prac nad projektem finansowanym ze środków Narodowego Centrum Nauki przyznanych na podstawie decyzji numer DEC-2012/05/N/HS2/01278. Pierwszą wersję tekstu przedstawiłam podczas zebrania Ośrodka Badań nad Awangardą Wydziału Polonistyki UJ. Uczestnikom tego spotkania bardzo dziękuję za dyskusję i za uwagi, które pozwoliły na dalsze uzupełnienia pracy.

1 Rozmowy o dramacie. Dramat religijny XX wieku. „Dialog” 1958, nr 6, s. 104.

2 J. Margań s ki, Gombrowicz - wieczny debiutant. Kraków 2001. 
wpierw mocnego zaprzeczenia, może nawet odcięcia, na pewno zaś - głębokiego wysiłku rewizji. I Błoński jako autor nowej książki nie jest tożsamy z Błońskim autorem tomu poprzedniego.

W słowniku krytyka zawsze bardzo ważnym terminem pozostawała „autentyczność”, Błoński poszukiwał jej u autorów, których darzył zainteresowaniem (ryzykując swego rodzaju przerysowanie, dałoby się nawet powiedzieć, że było to jedno z jego głównych oczekiwań wobec twórczości jako takiej), w równym stopniu wymagał jej jednak od siebie jako człowieka piszącego. Ma to określone konsekwencje dla sposobu myślenia o jego szeroko rozumianej działalności krytycznoliterackiej czy eseistycznej: tłumaczy przede wszystkim niejako piętrową jej strukturę; uzasadnia jedną z podstawowych technik Błońskiego, jaka było dodawanie nowych treści do wcześniejszych spostrzeżeń; wchłanianie dawniej opublikowanych szkiców przez następne książki. Wyjaśnia nieustanny ruch poprawiania samego siebie i dopisywania kolejnych dopowiedzeń czy eksplikacji.

Czego twórca szukał? Lepszych narzędzi, to pewne, trafniejszych diagnoz, obserwacji bardziej może przylegających do migotliwie zmieniającej się rzeczywistości. Co ważniejsze jednak - stale był na tropie takiej formuły krytyki, jaka nie fałszowałaby jego własnego doświadczenia; otwarty na świat zewnętrzny i jego przemiany, nie zapominał Błoński o tym, że krytyka ma sens o tyle, o ile potwierdzaja ją przeżycia samego komentatora; nie tylko stanowi kronikę literatury czy kultury, ale i - jak chciał kiedyś Oscar Wilde - jest ,jedyną cywilizowaną formą autobiografii” ${ }^{3}$. Samoświadomość twórcy Zmiany warty w tym zakresie okazywała się pewnie bardziej rozwinięta niż u innych i dość szybko zaczęła ulegać sproblematyzowaniu. W dzienniku z 1968 roku Błoński pisał:

Może i nie byłoby bez pożytku, gdybym umiał pokazać, jak rozszczepiały się - we mnie, ale zapewne nie ja jeden byłem w takim położeniu - przeświadczenia, które powinny były utrzymywać się, jeżeli nie $\mathrm{w}$ równowadze, to przynajmniej w określonym związku. $Z$ jednej strony, wiara $\mathrm{w}$ tradycyjnej formie - zwłaszcza na początku, kurczowo trzymająca się, niczym zaklęcia, określonych formuł, dogmatów, wskazań moralnych - z drugiej cała działalność intelektualna, będąca nie tyle grą, ile dociekaniem dziedzin nieznanych... dociekaniem zawsze w nawiasie, zawsze możliwym do odwołania. Przeto mogę powiedzieć, że byłem nieuczciwy intelektualnie i nawet niektórzy z moich przyjaciół niejasno to widzieli. Źródło „akademizmu” mojego w tym właśnie. W ujmowaniu formuł, odkryć, przeświadczeń intelektualnych jako narzędzi [...], jako rzeczy $w$ istocie, ponieważ mogłem je wziąć do ręki i odrzucić, jak odrzuca się rzecz, patrzeć na nie $z$ boku, jak na rzecz; natomiast nie można odrzucić siebie, swego doświadczenia, swego lęku. L. twierdził, że dopiero ostatnimi czasy - w szkicach o Norwidzie, o Sępie etc. - zaczęło wyglądać moje ,ja” prawdziwsze: nie jestem jednak pewien, czy to istotnie najlepsze moje rzeczy ${ }^{4}$.

Daleko szła ta samokrytyka - Błoński bowiem potrafił uchwycić paradoks: ruchliwości intelektualnej, poświadczonej przecież mnóstwem tekstów napisanych przez niego do tego czasu, przeciwstawiał nieruchomość dogmatu, rozumiana jako ucieczka w pewniki, nie domagające się żadnego uzasadnienia. Oskarżał się przy tym głównie o brak uczciwości intelektualnej, którego początków należałoby szukać w mechanizmach petryfikacji i znieruchomienia; wytykał samemu sobie to, że nie

3 O. Wild e, Krytyk jako artysta. W: Eseje. - Opowiadania. - Bajki. - Poematy proza. Red. J. Żuławs ki. Warszawa 1957, s. 53 (przeł. C. Woj ew od a).

4 J. Błoń s ki, Dziennik. W: Błoński przekorny. Dziennik. - Wywiady. Zebrał i oprac. M. Za c zy ńs ki. Kraków 2011, s. 91-92 (zapis z 27 I 1968). 
umie pogodzić najbardziej osobistych przeżyć z działalnością umysłu, co więcej - że nigdy porozumienia między tymi sferami nie szukał. Wiara - mówił, dotykając spraw najgłębiej intymnych - a i owszem, ale zbyt często sprowadzona do dogmatu, usztywniona; lecz dzięki temu bezpieczna. I fascynacja myśla - tak pociagająca dlatego właśnie, że nie traktowaną zbyt poważnie; fascynacja będąca rodzajem niczym nie poświadczonej pracy intelektu, zachwyconego kryjącymi się w nim możliwościami konceptualizacji.

Wyrzucał sobie zatem Błoński - zapewne niesprawiedliwie - tak naprawdę to, że żadnego $\mathrm{z}$ wymienionych obszarów nie traktuje do końca serio. Jeżeli bowiem (dopowiedzmy, co pozostaje tu ukryte) udałoby mu się $z$ najwyższą powagą nad tymi kwestiami zastanowić, musiałby dokonać znaczacej rewaloryzacji: wiara zyskałaby na dynamice, myślenie zaś - na swoiście rozumianej stabilności, nie miałoby już w sobie wiele $z$ czczej i rozproszonej gonitwy, raz po raz chwytającej się nowych tematów, potwierdzałoby natomiast kształt najistotniejszego doświadczenia, niejako je dokumentując i uspójniając. Szukał więc Błoński również takiej formuły, która scaliłaby myśl - z życiem. Gotowa jestem postawić tezę, że cała późniejsza krytyka tego autora wynika $\mathrm{z}$ przepracowania owych prostych założeń sformułowanych pod koniec lat sześćdziesiątych $\mathrm{XX}$ wieku w dzienniku: stanowi próbę przełożenia osobistych obsesji na język intelektu, jest poszukiwaniem formy, w której myśl tę można powierzyć czytelnikowi. W katalogu owych obsesji intuicje metafizyczne zajmują jedno $z$ głównych miejsc, w konsekwencji zaś należą do najważniejszych tematów Błońskiego jako krytyka.

Skala intymizacji jego dyskursu krytycznego zwiększa się przy tym wyraźnie z czasem i jeżeliby zaufać opinii Andrzeja Sulikowskiego, twierdzącego, że dla Błońskiego rozproszone teksty nie miały większego znaczenia, ufał on treściom pomieszczonym w książkach ${ }^{5}$ - to za otwartą wykładnię tych przekonań można by uznać dopiero Kilka myśli co nie nowe (1985). Pisał po ich ukazaniu się Krzysztof Mętrak: „Jan Błoński doszedł do fazy "metafizycznej" i - nieco paradoksalnie - przywróciło go to, na wyższym piętrze, całkiem aktualnym potrzebom czytelniczym”6. Sęk w tym, że owa „faza metafizyczna” u Błońskiego trwała już - na poziomie, który byłby poświadczony tekstowo - co najmniej od lat 20 , tyle że regularnie usuwana $z$ pola widzenia przez większość współczesnych mu komentatorów, konsekwentnie pomijających ową dominantę myślenia. Moim dzisiejszym celem jest próba zastanowienia się nad genealogią części pojęć występujących w tym projekcie, pokazania, $z$ jakich tradycji były one wyprowadzane, a także rozważenia, jak wykorzystywał je Błoński do oceniania kultury polskiej - której wyrzucał przecież (za Stanisławem Brzozowskim) - fundamentalną antymetafizyczność.

$Z$ wielu wątków pojawiających się w pisarstwie Błońskiego w latach sześćdziesiątych $\mathrm{XX}$ wieku odnoszących się do zarysowanej problematyki wybieram w tym miejscu

5 A. Sulikowski, Spotkania z Janem Błońskim. Na siedemdziesięciolecie urodzin. W zb.: Jan Błoński... i literatura XX wieku. Red. M. Su gi era, R. Ny c z. Kraków 2002, s. 137.

6 K. Mętrak, „Uchwyt” Błońskiego. „Literatura” 1986, nr 7/8, s. 45. 
tylko takie, które dotyczą szeroko rozumianego eksperymentu ${ }^{7}$. Sądzę bowiem, że w owym czasie działalność intelektualna krytyka opierała się w dużej mierze na jednym ważnym zabiegu: radykalnej przebudowy własnego projektu myślenia o kulturze w nawiązaniu do tradycji (jak to brzmi!) francuskojęzycznej awangardy sensu largo. Interesują Błońskiego w niej przy tym dwa nurty - powiązane ze sobą, ale jednak nie tożsame. Podstawę pierwszego $\mathrm{z}$ nich stanowią akty zwielokrotnionego świętokradztwa czy bluźnierstwa, przez negację i zaprzeczenie wzmacniającego i uwiarygodniającego sacrum (te kategorie uruchamiać będzie krytyk, pisząc o twórczości Jeana Geneta czy Michela de Ghelderode'a ${ }^{8}$ ), drugiego zaś - próby przywrócenia sakralności samej kulturze (stąd u autora Zmiany warty Antonin Artaud, Marcel Proust, wizja powieściowego arcydzieła - pragnienie i marzenie o totalności). Mówiąc inaczej, Błoński zajmuje się przedstawianiem kondycji mieszkańców Ziemi Ulro ${ }^{9}$ (i słusznie wyczuwa, że istotą tej kondycji jest rozpaczliwa dialektyka wiary i niewiary), bardziej jednak od Czesława Miłosza zdaje się ufać temu, że kultura wypracowała niegdyś jeszcze rzeczywiste przeciwciała - i okazuje się jakoś urzeczony radykalizmem negacji, projektem, który często musi balansować na pograniczu choroby i szaleństwa.

Koncepcja „odwróconego sacrum” - w pełni rozwinięta i sformułowana dopiero w szkicu To co święte, to co literackie - była przez Błońskiego obmyślana co najmniej

$7 \quad$ Decyzję taka podyktowało przede wszystkim przeświadczenie, że skoncentrowanie się na zespole pochodzących $z$ lat sześćdziesiątych XX w. prac Błońskiego dotyczących baroku - a więc głównie na książce o Sępie Szarzyńskim - temat ten by niepotrzebnie upraszczało, bo są to teksty krytyka, w których problematyka owa została poruszona z oczywistych względów. Zob. stanowisko K. D y bc i a k a (Kilka myśli o Janie Błońskim. W: Wokót czy $w$ centrum literatury? Studia o krytyce i eseju. Warszawa 2016) - w podobny sposób wyznaczał on dynamikę zainteresowań Błońskiego, ale inaczej uzasadniał fakt stosunkowo późnego otwartego eksponowania wyraźnie chrześcijańskiej podszewki myślenia w pismach tego autora. Dybciak przede wszystkim zwracał uwagę na kontekst sytuacyjny: akcentował znaczenie uwarunkowań politycznych i światopoglądowych (katolicyzm jako wybór pozostający w kontrze względem postaw wyraźnie zlaicyzowanej większości). Podkreślał przy tym, że w stanowisku Błońskiego można odnaleźć ślady wchodzenia w rolę „kryptokatolika”, zdającego sobie sprawę $z$ faktu, iż jego argumentacja będzie miała większą siłę oddziaływania, gdy uwolniona zostanie od brzemienia nachalności i - co ważniejsze nawet - gdy forsowana będzie przez osobę uczestniczącą w życiu kulturalnym, cieszącą się uznaniem i autorytetem (ibidem, s. 275-276). W moim przekonaniu czynniki zewnętrzne nie miały tak dużego znaczenia, wielopoziomowe strategie pseudonimowania tematyki religijnej i ostrożnego jej wprowadzania w różnych postaciach czytam bowiem nie tyle jako rodzaj gry z oczekiwaniami odbiorcy (w tym: cenzury), ile raczej jako zapis procesu obejmującego wewnętrzne dojrzewanie do zmierzenia się z problematyką, która wydaje się doświadczeniem fundamentalnym.

8 Celowo pomijam w tym miejscu najważniejsze teksty Błońskiego dotyczące teatru absurdu, tj. głównie analizy i interpretacje twórczości E. Ionesco i S. Becketta. Teksty te zostały wnikliwie omówione przez M. Sugierę (Błoński $w$ oparach absurdu. W zb.: Jan Błoński... i literatura $X X$ wieku, s. 79), co istotniejsze jednak - mieszczą się one tak naprawdę w innym porządku. Zgadzam się bowiem $z$ bardzo trafnym komentarzem przywołanej badaczki, która - przedstawiając metodę stosowaną przez Błońskiego w odniesieniu do tego tematu - podkreślała zaskakujący chłód owych rozważań (spokrewniający je $z$ „poetyką normatywna”), by wskazać, że ten dystans jest zabiegiem w pełni celowym, jakby autor „obawiał się, że wykładając ich [tj. Ionesco i Becketta] racje, wsączy w dusze swoich czytelników naganny sceptycyzm czy wręcz - nihilizm" (ibidem, s. 79). Jest to sformułowanie nieco ahistoryczne, bo w chwili, gdy Błoński rozpoczynał tę refleksję, Ziemia Ulro Cz. Miło s za jeszcze nie istniała, została opublikowana dopiero w 1977 roku. 
od połowy lat sześćdziesiatych XX wieku. Jej zarys wykładał krytyk po raz pierwszy w liście do Anny Micińskiej, powołując się na doświadczenie pracy z Konradem Swinarskim ${ }^{10}$, na którego potrzeby przygotowywał nowe tłumaczenie Pokojówek Geneta. Pisał wówczas:

Swinarski jest człowiek niegłupi. Ponieważ poszliśmy zaraz na obiad, wyznał, upraszczając nieco sprawę - że interesuje go tylko bluźnierstwo, tzn. pretensje do Pana Boga za to, że „tutaj” tak nieszczególnie urządzone; ten metafizyczny jęk, który nie był kabotyński, tylko jakoś wstydliwie z siebie wydarty, znajduje zresztą pokrycie w sposobie, w jaki [Swinarski] poprowadził sztukę reżyserską; i Genet jest zreszta podobny. Daje to do myślenia w tym sensie: że odnajduję może nie to samo, ale podobną fascynację „odwróconym sacré” u tak wielu ludzi, i najwybitniejszych. Zdaje sobie Pani sprawę, że, by pozostać w teatrze, i Brookowi o to chodzi, i Artaudowi, i oczywiście Grotowskiemu, gdzie nawet najświadomiej (chociaż trudno to explicite rozważać, zważywszy na okoliczności). Czyżby wi ęc, póki Europa Europa, nie potrafi się ona wyplątać $z$ własnej religii, choćby z jej „czarnego” braku, antyreligii - czyżby, mówiąc po prostu, ona była swoją religią - i nawet w jej odwróceniu odnajdywała jeszcze swą tożsamość, która jej nie przestaje zresztą uciekać? Mnie to o tyle nie dziwi, że tak od dawna podejrzewałem (i, chociaż to może Panią zaskoczyć, właśnie studia nad Sępem bardzo mnie w tym umocniły) - co mnie zaskakuje, to to, że u tylu ludzi odnajduję analogiczne troski... oczywiście w zupełnie innym, i zapewne lepszym i płodniejszym, wydaniu. Nasuwa się mnóstwo zawrotnych myśli, marzeń i przypuszczeń, zwłaszcza jeżeli zestawić problem z przyszłością sztuki w ogóle (Witkiewicz, oczywiście), ze sprawą kultury masowej (czytałem książkę Morina właśnie, którą ośmielam się zalecać), z zadziwiającymi fenomenami, które i na Wschodzie, i na Zachodzie niewyraźnie się rodzą. Ale to już wychodzi właściwie poza listowne porozumienie, bo lęk zdejmuje przed pisaniem głupstw tak bardzo niejasnych. Co pewne, to przyspieszony proces rozszczepiania się kultury naszej na coraz bardziej oddalające się dziedziny i kierunki: ucieczka mgławic. Że nic dobrego z tego nie wyniknie, to też pewne ${ }^{11}$.

Odnajdujemy więc w tej koncepcji (ledwie tu szkicowanej) od razu to, co stanowi jej sedno: przeświadczenie, że religia - konkretnie zaś chrześcijaństwo - jest dla Europy tak ważkim punktem odniesienia, iż nie umie go ona odtrącić; nawet radykalna negacja okazuje się bowiem pozostawaniem w ścisłym związku; język kategorii religijnych organizuje naszą wyobraźnię. Julia Kristeva powie po latach: „byt mówiący to byt wierzący” ${ }^{2}$, a Błoński wciąż krążyć będzie wokół pytania zadanego przez nią z taka jasnościa - o „niewiarygodna potrzebę wiary”, o słowniki antyreligii, o to, jak (pozornie zsekularyzowana) wyobraźnia Europejczyków będzie

10 Kontakty Błońskiego z K. Swinarskim wnikliwie przeanalizował - na podstawie rozproszonych tekstów - G. Niziołek (Błoński o Swinarskim. Od „Wyzwolenia” do uwolnienia. „Wielogłos” 2014, nr 4). W dokonanej przez niego rekonstrukcji myśli krakowskiego krytyka dwa aspekty wydają mi się szczególnie znaczące: 1) zwrócenie uwagi na wyraźnie konserwatywny wymiar wypowiedzi komentatora, niejako „temperującego” autokomentarz Swinarskiego, a zarazem łagodzącego bądź nawet anihilującego jego radykalizm polityczny; 2) wyeksponowanie ambiwalencji zainteresowań Błońskiego, który chciał teatr Swinarskiego czytać, z jednej strony, przez pryzmat mocno akcentowanej metafizyki, $z$ drugiej wszakże - również przez to, co niskie, zaprzeczające wzniosłości: „[...] Błońskiego ciekawił także cynizm Swinarskiego, jego skłonność do zohydzania tego, co zbyt harmonijne, zdolność do manipulowania cudzymi emocjami, przewrotna radość ze szczucia na siebie aktorów. Wszystkie te dosadne określenia ("zohydzanie", "manipulacja" i "szczucie") pochodzą od Błońskiego" (ibidem, s. 27). W świetle omawianych tu przeze mnie poglądów krytyka owa podwójność nie dziwi, wprost przeciwnie - pokazuje raczej, jak bardzo konsekwentne było to myślenie, mocno wyczulone na coś, co wolno chyba nazwać zanieczyszczeniem sacrum.

11 J. Błoń s ki, list do A. Micińskiej, z 15 XII [1966]. Archiwum A. Micińskiej. Bibl. Narodowa w Warszawie. Podkreśl. M. Sz.

12 J. Kristeva, Ta niewiarygodna potrzeba wiary. Przeł. A. Tu r czy n. Kraków 2010, s. 19. 
starała się odnaleźć dla siebie jakiś rodzaj ersatzu, niebezpiecznie pociagający, nawet (a może zwłaszcza) dla najbardziej prawowiernych. Pytania Błońskiego w ogóle nie dotyczą przyczyn buntu, nie idą - jak u Swinarskiego, przywołanego w cytowanym liście - w stronę „pretensji do Pana Boga za to, że "tutaj" tak nieszczególnie urządzone”, odsuwają na boczny tor wielość drastycznych doświadczeń $\mathrm{XX}$ wieku. Uwaga piszącego zawsze będzie skoncentrowana na czym innym: na negatywistycznym ujęciu konfesji, na skrajnym radykalizmie tej paradoksalnej apofatyki. Jeśli bowiem nawet nie kryje się w tych próbach jedyne możliwe dziś ujęcie doświadczenia religijnego, to niewątpliwie - wedle odczytania dokonywanego przez Błońskiego - zamyka się w nich doznanie szczególnie prawdziwe: poświadczone głębią indywidualnego przeżycia. Grymas protestu wydaje się więc szczerszy od frazesu afirmacji.

Komentatorów Błońskiego - także tych zupełnie współczesnych - zawsze interesowali raczej właśnie ci „bluźniercy” niż „wariaci”. Nic w sumie dziwnego - pytanie o świętokradców najprecyzyjniej może zadawał Stefan Chwin, zastanawiając się, jak autor Zmiany warty potrafił pogodzić żarliwość wiary z zamiłowaniem do wykolejeńców, wiarę tę wywracających na nice ${ }^{13}$. Błoński po latach bronił się będzie niejako pokazywaniem jałowości i nudy stojącej za literatura jednoznacznie katolicką. Ale przecież nie tylko ze względu na to, że zupełnie pozbawiona była ona sex appealu, opowiadał się krytyk za innymi tekstami. Swoje stanowisko wykładał bardzo klarownie jeszcze pod koniec lat pięćdziesiątych XX wieku, gdy redakcja „Dialogu” zorganizowała dyskusję na temat współczesnego dramatu religijnego. Stwierdzał wtedy, wyraźnie dystansując się od typologii proponowanych przez pozostałych dyskutantów:

Grozi nam [...] niebezpieczeństwo zawężenia tematu. Jeżeli mówimy: dramat religijny, myślimy: dramat ludzi wierzących, chrześcijan, katolików. Tymczasem ja to widzę nieco szerzej. Nie można w sztuce - rozdzielać religii od filozofii, od wszelkiej ideologii. Religijne interpretacje muszą się pojawić wszędzie tam, gdzie istnieje „świadomość metafizyczna”. I dlatego nasuwa mi się od razu na myśl choćby teatr awangardowy, tak pozornie daleki od tematu naszej dyskusji... ${ }^{14}$

Jasno więc Błoński deklarował, że nie interesuje go takie myślenie o funkcjonowaniu religii w literaturze, jakie można by nazwać ilustracyjnym. I w rzucanych wtedy mimochodem uwagach formułował szereg istotnych dla niego intuicji: pokazywał bowiem de facto swoim rozmówcom, że myślenie takie okazuje się dziś nie-

S. Chwin, głos w dyskusji. W: Jan Błoński. Portret wielokrotny. Rozmowa z udziałem Stefana Chwina, Jerzego Jarzębskiego, Mariana Stali, Małgorzaty Sugiery i Marty Wyki. „Dekada Literacka” 2009, nr 3. Na stronie: http://www.dekadaliteracka.com.pl/?id=4707 (data dostępu: 10 II 2017). Pisarz mówił też: „Najbardziej tajemnicza - jego [tj. Błońskiego] religijność. To ona najbardziej przyciagała moje pióro. W pogrzebowej homilii ksiądz Boniecki powiedział, że Błoński wierzył jak dziecko. Jak dziecko? Ciekawił mnie jako intelektualista katolicki, to znaczy ktoś zupełnie niepodobny do mnie. Inteligentów katolickich mamy pod dostatkiem, ale katolicki intelektualista? Ta różnica była inspirująca" (ibidem).

14 J. Błoń s ki, głos w dyskusji. W: Rozmowy o dramacie, s. 95. Podkreśl. M. Sz. 
możliwe, rozmija się wszak z rzeczywistym przeżyciem religijnym współczesnego człowieka, jest więc w najlepszym razie próbą reaktywacji przestarzałych wzorców. Za istotę dzisiejszej wiary (nie definiowanej, oczywiście, wprost) uznawał zatem Błoński tak naprawdę jej migotliwość: jeśli dobrze go pojmuję, wierzył on w to, że wiara nie stanowi prostego continuum, wymaga ciagłego wysiłku podtrzymywania jej w sobie - i pracy. Proszę mnie dobrze zrozumieć: nie imputuję Błońskiemu, że nie postrzegał on wiary w kategoriach łaski. Sądze jednak, iż bardzo istotnym punktem odniesienia pozostawała dla niego świadomość nieoczywistości w i a ry; i tak, jak w wieku XVI niemożliwe było myślenie poza nią, tak w wieku XX jest ona stale ponawianym wyzwaniem - i zadaniem ${ }^{15}$. Dystans Błońskiego wobec dramatu religijnego (w jego zawężonym rozumieniu) wypływał niewątpliwie z przeświadczenia, że jest on zbyt statystyczny, dokumentuje tylko istniejące już przekonania, unika pokazywania procesu.

Bardzo ważną figura w dyskursie Błońskiego pozostaje katechumen. W tej samej rozmowie krytyk dodawał:

Zastanawiam się, czy pozycja katechumena nie jest dziś - literacko! - częstsza i płodniejsza niż pozycja człowieka, który dokonał już ostatecznego wyboru. Pisarz powinien może raczej wracać do punktu, gdzie wszystko odkrywa na nowo. Może to jest właśnie punkt, z którego można najpełniej objąć ów „dramat tajemnicy”? O ile mogę przypuścić, dawniej tak twórcy nie odczuwali - jest to coś charakterystycznego dla naszego wieku ${ }^{16}$.

I jeżeli Błoński chętnie wracał do teatru awangardowego, szukając w nim nowoczesnej metafizyki, to dlatego głównie, że ufał w oczyszczająca moc prowokacji; w to, że zarówno wiare, jak i światopogląd jako taki należy poddawać próbie. Próbie jednak nie wymykającej się spod kontroli: jak za chwilę zobaczymy, bliska była twórcy Zmiany warty koncepcja sztuki, w której ta stawała się rodzajem laboratorium - przeprowadzany w niej eksperyment miał więc granice.

Takie rozumienie zarówno próby, jak i roli sztuki można odnaleźć w tekstach krytyka o autorach tak różnych, jak wspomniani już de Ghelderode i Genet ${ }^{17}$. Pierwszy z nich interesował Błońskiego z powodów w sumie dość zachowawczych, by nie powiedzieć: tradycyjnych - jego działalność dramaturgiczna krytyk postrzegał jako odnowienie języka i formuły misterium; misterium - a i owszem - zniekształconego, groteskowo przetworzonego, bardzo mocno jednak zakorzenionego

Błoński znał doskonale m.in. obszerna pracę L. F ebvr e'a Le Problème de l'incroyance au XVI. La religion de Rabelais (Paris 1942), która wpłynęła na sposób ujęcia religijności Sępa Szarzyńskiego w monografii mu poświęconej. Ten kontekst - uwypuklany przez samego krytyka - ma duże znaczenie; refleksja nad „pozornymi ateistami” - jak zdawał się postrzegać Błoński wielu twórców XX-wiecznych - ufundowana jest bowiem niewątpliwie na ruchu wcześniejszego przemyślenia przemian rozumienia religii w tradycji Zachodu. Tu też bierze swój początek (mało znane) zainteresowanie Błońskiego projektami L. Kołakowskiego, który - za pomocą innego języka - próbował przedrzeć się przez podobną problematykę.

Błoń s ki, głos w dyskusji, s. 103.

17 Krytyk poświęcił im w drugiej połowie lat pięćdziesiątych XX w. kilka tekstów, które wyprzedza jego właściwe zainteresowanie twórczością E. Ionesco - zob. J. Błoń s ki: Michel de Ghelderode. „Dialog” 1956, nr 4; Wprowadzenie do Geneta. Jw., 1959, nr 6; „Balkon”, czyli zabójstwo Boga. Jw., nr 10. Przedruk w: Między literatura a światem. Wybrał, oprac. J. J a r z ę b s k i. Kraków 2002 (cytując szkic, korzystam z tego wydania). 
w tradycji. Kierunek myślenia Ghelderode’a okazywał się więc wywrotowy, ale nie ze względu na jego awangardowość, lecz wprost przeciwnie $-z$ racji umiejętności odnowienia nurtów silnie osadzonych w kulturze. Bądź też - mówiąc inaczej - najbardziej awangardowe stawało się powtórzenie. Najważniejszym tematem Ghelderode’a była w tym ujęciu tak naprawdę karnawalizacja, odwracająca porządek sacrum i profanum; karnawalizacja rozgrywająca się zazwyczaj w świecie jawnie nawiązującym do realiów epoki Pietera Bruegla. Błońskiemu ten kierunek myślenia musiał wydawać się niezwykle interesujący, bo na jego marginesie krytyk miał szansę stawiać pytanie o to, jak można widzieć to rozgraniczenie w świecie, który przydaje religii inne znaczenie; słowem - co w tym wypadku osiagnie się, podejmując wysiłek transpozycji. Czy naruszanie reguł, piętrzenie okrucieństw, prześmiewstw i kpiny - będące kiedyś jednym $z$ gwarantów porządku - nadal oznacza i może oznaczać to samo. I Błoński zdawał się odpowiadać: chociaż zmieniło się wszystko, to w tym zakresie nic się nie zmieniło - twórcy tacy jak belgijski dramaturg są niezbędni do tego, by utwierdzić nas w przeświadczeniu, że istnieje coś „poza”; szyderstwo odnajduje uzasadnienie. Niewatpliwie uspokajała przy tym krytyka myśl, że wyobraźnia Ghelderode’a - choć skoncentrowana na pogłębianiu i intensyfikacji drwiny - nie wychodzi poza chrześcijański światopogląd: warunkiem każdego świętokradztwa jest przecież zgoda co do tego, że przedmiot zniewagi mieści się w kategoriach świętości.

Refleksja Błońskiego nad Genetem ${ }^{18}$ sytuuje się, jak się wydaje, w innym nieco porządku. W To co święte, to co literackie krytyk powie po latach:

W literaturze szczególnie często mistyka objawia się w stanie dzikim. Jeśli tak, wolno mi wezwać na świadków pisarzy, których metafizyczne [...] znaczenie przejawia się w formach zaskakujących i nieznanych czytelnikowi ${ }^{19}$.

Światy stwarzane przez Ghelderode'a - w zestawieniu z tymi, w które wtajemnicza nas Genet - przypominają raczej ugrzecznioną wersję dla dzieci. Analizując szczegółowo Balkon, Błoński przeprowadza nas przez poszczególne etapy rozumowania autora - i zastawianych na odbiorcę pułapek:

Genet pisze zawsze przeciw widzowi: tworząc swego Naczelnika, może upiec dwie pieczenie przy jednym ogniu. Przyjmijmy naprzód, że widz szanuje policję, stoi po stronie porządku, dobra, sprawiedliwości. Kiedy ujrzy Naczelnika z Balkonu, będzie oburzony i przerażony: jeśli bowiem policjant jest nikczemnikiem, gdzież jest porządek i społeczny ład? Nigdzie; zwycięża zło. Przyjmijmy teraz, że widz nie jest konformista, że policją pogardza i najwyżej stawia bunt. I on również będzie zdumiony i rozgniewany: przecież wartości, które szanuje (inne niż wartości człowieka „sprawiedliwego”, ale również

Bardzo ciekawe jest przy tym skonfrontowanie tych odczytań z zupełnie współczesnym językiem interpretacji, jaki proponuje P. S. Ro sół, sytuujący twórczość Geneta w kontekście postchrześcijaństwa (Święty przeklęty, przegięty święty. Jean Genet i postchrześcijaństwo. „Kresy” 2010, nr 1/2). Zwracając uwagę na to, że postchrześcijaństwo nie jest u Geneta jedynie ozdobnikiem bądź tematem, Ro sół pokazuje, w jaki sposób wpływa ono organicznie na konstrukcję tekstu. Szczególnie istotne dla omawianych tu przeze mnie fragmentów wydają się wypowiedzi dotyczące obrzydliwości jako fundamentu moralności (post)chrześcijańskiej i tego, co się wydarza, gdy ten zapoznany bądź wypierany wymiar powraca u Geneta ze zdwojoną siłą (ibidem, zwłaszcza s. 13-15). Owe komentarze dotyczące natury grzechu uznać można tak naprawdę za pomost między rozważaniami Błońskiego nad bluźniercami a refleksjami Miłosza - to dwa rodzaje medytacji nad formami skażenia. 
wartości) zostały wcielone w ohydna postać policjanta. I tym razem więc zło bierze górę. Genet pragnie bowiem skompromitować wszelką wartość, zarówno konformizm, jak nonkonformizm, zarówno prawicę, jak lewicę: wszystko, przy czym ktokolwiek może postawić znak plus. Im bowiem plugawszy, tym dla Geneta lepszy: ze swej hańby czerpie on swoją chwałę ${ }^{20}$.

Krytyka fascynuje - ale i odpycha przecież? - radykalizm tych założeń. Opisywany piórem Błońskiego, Genet wydaje się przeradzać w możliwie najbardziej skrajnego kontynuatora (nie wspomnianego w tekście) Fiodora Dostojewskiego kontynuatora wyciagającego $z$ dzieł twórcy Zbrodni $i$ kary ostateczne wnioski. Śmierci Boga towarzyszy zrazu pragnienie człowieka, by stać się bogiem; świat Geneta jest światem relacji, opartym na interakcyjności - odmienny wymiar istnienia (bez oglądania się w oczach innych) w ogóle nie wydaje się możliwy. I ono zostaje wszakże skompromitowane. Przeradza się w pozór, który także ulegnie unicestwieniu. W konsekwencji stajemy się świadkami mechanizmu rozpędzonej autodestrukcji; świadkami tyleż nie mogącymi oderwać oczu od spektaklu, ile przerażonymi. Mówiąc inaczej - Genet, w odczytaniu Błońskiego, zdaje się dostarczać odbiorcy możliwości udziału w misterium tremendum ${ }^{21}$ -

Nasycony bluźnierczą sakralnością, [Balkon] przejmuje [...] grozą, jeśli tylko - choćby na chwile uznać pracowite sofizmaty Geneta. Nabiera on sensu tylko w teatrze tajemnym, teatrze w katakumbach: widzów winna śledzić i surowo karać policja. Jest to prawdopodobnie ostatni paradoks Geneta ${ }^{22}$.

Zarówno porządek akceptacji reguł narzuconych odbiorcy, jak i nieprzyjęcie ich - przekonuje Błoński - wpisane są tu niejako w założoną logikę odbioru dzieła; tym samym ma ono w pewnym sensie przymusowy wymiar katarktyczny; zmienia nawet tych, którzy nie chca podlegać zmianie; zmusza do kontaktu z sacrum może już nawet nie odwróconym, lecz przekreślonym.

Pisał w latach sześćdziesiątych Błoński o Gombrowiczu, że prozaik ten go pociaga, ale zarazem jest mu obcy. Sądzę, że do działalności „bluźnierców” miał podobny stosunek: nieprzypadkowo spokrewniał autora Ślubu z Genetem²3. Krążył jednak wokół nich, urzeczony niejako samą próbą odbudowy języka metafizycznego - koncepcja odwróconego sacrum nie zakładała przecież porządku afirmacji; pokazywała tylko, że nie ma ucieczki poza matrycę myślenia religijnego; innymi słowy - że nawet zamiana biegunów, próba zastapienia Boga człowiekiem, nie jest niczym więcej niż walką w obrębie tego samego (choć przesilającego się na naszych oczach) paradygmatu; walką istotna, ba!, fundamentalna - bo tak charakterystyczną dla epoki. Jeśli jednak refleksja nad opisanymi dramaturgami była u Błońskiego formą diagnozy, to gdzie indziej szukał on rozwiazania.

Nad obecnością „wariatów”, proroków rewolucji i prawodawców zmiany w tekstach Błońskiego zastanawiano się rzadziej - a mnie od jego świętokradców o wiele bar-

20 Błońs ki, „Balkon”, czyli zabójstwo Boga, s. 31.

21 Termin R. Otto.

22 Błoń s ki, „Balkon”, czyli zabójstwo Boga, s. 36.

23 To zestawienie koncepcyjnie zostało w pełni rozwinięte dopiero niedawno - zob. studium P. S. Ros oła Genet Gombrowicza. Historia miłosna (Gdańsk 2016). 
dziej interesuje Artaud w jego pismach ${ }^{24}$. Bo jakkolwiek przewrotnie by to brzmiało, $\mathrm{z}$ dzieł autora Teatru i jego sobowtóra wyciagał Błoński program pozytywny (swoiście rozumiany), to od tego twórcy brał narzędzia bądź uczył się kategorii, jakie pozwalały mu na pokonanie zarówno wewnętrznego rozłamu, jak i pęknięcia kultury, którą chciał reformować. Posłuchajmy wpierw fragmentu brzmiącego niczym bezpośredni komentarz do cytowanego przeze mnie na wstępie urywka dziennika, nazywającego wyrażone w nim tęsknoty i proponującego remedium:

Podobnie jak sztuka cała lub raczej: jak wszelka duchowa działalność, teatr ma zmierzać do pogodzenia człowieka z nim samym i z kosmosem, budować c złowieka pełne go, w którym systemy nie będą kłócić się $z$ odruchami, światopogląd z praktyką postępowania, trudy myśli $z$ poruszeniami ciała, ambicje osobiste $z$ funkcją społeczną ${ }^{25}$.

Ten Artaudowski człowiek pełny - marzenie Błońskiego - pełnię swą osiaga za pomocą sztuki, to teatr (pojmowany jako forma rytuału) jest w stanie przeprowadzić go przez jego ograniczenia, zasklepić sprzeczność między myślą a życiem. Błoński pisze:

[...] Artaud [...] rozumie [...] widowisko jako gwałcenie miary, reguły i przepisu. Nasycone wszakże sakralnym znaczeniem: pozwala mianowicie wejść w porozumienie $z$ siłami chaosu, $z$ tym, co było przed początkiem i ufundowało świat. Teatr odpowiada u Artauda czasowi święta: okrutnego, świętokradczego i twórczego [...]. „Teatr, jak dżuma, jest kryzysem, który rozwiązuje się śmiercią lub wyzdrowieniem”. Świat odrodzi się lub zginie. „Nie jesteśmy wolni. I niebo może nam jeszcze runąć na głowy. I teatr po to istnieje, by nas tego przede wszystkim nauczyć”. Aby uzmysłowić nam nie dramat ludzki, lecz kosmiczny ${ }^{26}$.

Wprowadza nas Błoński tym samym o poziom wyżej niż w wypadku Ghelderode'a: rozwiązania belgijskiego dramaturga pokazywały jedynie nierozerwalność czasów sacrum i profanum; niezbędność profanacji. Propozycja Artauda - dla Błońskiego zdecydowanie atrakcyjniejsza - jest bez porównania bardziej ryzykowna: stawka w tej grze okazuje się najwyższa, toczy się ona o przeistoczenie - już nie

24 Warto przypomnieć, że przygotowana przez Błońskiego - we współpracy z K. Puzyną - edycja pism Artauda stanowiła kolejną spośród całkiem licznych przedtem prób wprowadzenia tego twórcy do polskiej świadomości kulturalnej. Najważniejszym z poprzedników Błońskiego na tej niwie niewątpliwie był A. Falki ew i c z, który przypominał tę postać w artykułach publikowanych na początku lat sześćdziesiątych XX w. (Witkacy, Artaud i awangarda. „Dialog” 1960, nr 6; Myśli o Antoninie Artaud. „Pamiętnik Teatralny” 1961, z. 4), a także doprowadził do wydania (na łamach „Pamiętnika Teatralnego") fragmentów Teatru i jego sobowtóra (w tłumaczeniu H. Szymańskiej) zob. Z. O s iń s k i, Polska recepcja Artauda. „Dialog” 1998, nr 3, s. 132-133. Błoński do Artauda dotarł jednak raczej niezależnie od Falkiewicza: za sprawą wzrostu popularności tego pisarza we Francji, jaki można datować na drugą połowę lat pięćdziesiątych XX w. - pierwsze ważniejsze inicjatywy Artaudowskie zbiegły się w czasie z pierwszymi dłuższymi pobytami Błońskiego w tym kraju (w 1957 roku). Sam zaś kierunek interpretacji Artauda - proponowany przez Błońskiego wskazuje na więcej zbieżności z myśleniem, które mocno zaczęło dominować zarówno we francuskiej, jak i w polskiej refleksji kulturowej (tu dzięki książce L. Kolan ki ewi c za Święty Artaud 〈Warszawa 1988〉) w latach osiemdziesiątych: eksperyment Artauda interesuje bowiem krytyka nie tyle jako rewolucjonizowanie granic teatru, ile raczej jako laboratorium egzystencji.

25 J. Błoń s ki, Artaud i teatr magiczny. Wstęp w: A. Arta u d, Teatr ijego sobowtór. Przeł. J. Błoński. Noty J. Błońs ki, K. Puzyna. Warszawa 1966, s. 17.

Ibidem, s. 19. 
człowieka nawet, lecz całego świata. U Artauda interesuje Błońskiego taki wymiar doświadczenia, jaki nie pojawiał się u wspomnianych wcześniej artystów, a więc to, co najbardziej pierwotne, przestrzeń Chaosu, jakoś teraz wtórnie przywołana. Oraz cały skomplikowany system kontaktu $z$ tą sfera, oparty na rygorystycznym porządku rytuału; rytuału, który (jak podkreśla Błoński) z jednej strony trzyma w ryzach anarchię, $z$ drugiej stara się ją sfunkcjonalizować. Sztuka - mówi za Artaudem krytyk - jest forma transu: ma w całości przekształcić uczestników widowiska, nadać im nową jakość. Aby się to dokonało, sztuka nie może być dla odbiorców czymś zewnętrznym. Artaud przeciwstawiał się tradycyjnemu teatrowi m.in. dlatego, że ten błędnie pojmował rolę widza. Koncepcja francuskiego dramaturga zabrania odbiorcy zajmowania stanowiska obserwatora - nacisk w pełni położony zostaje na aktywizm; obie strony są odpowiedzialne za widowisko, mają wpływ na to, czy proces się uda. Artaud bardzo mocno akcentował przy tym momentalność - to, co się wydarza, wydarza się w liczbie pojedynczej; każda kolejna odsłona będzie już inna.

Jak się wydaje, Błońskiego jakoś najbardziej pociąga w radykalizmie tej propozycji jej wymiar demiurgiczny: „Magiczne od- i przetwarzanie świata zakłada osiagnnięcie jedności ducha i materii” - pisze krytyk i pobrzmiewa w tym groza wielkości. „Sakralne jest to, co łączy” ${ }^{27}$ - notuje na marginesie. I zaraz każe postawić pytanie, czy tę wyzwalającą teorię można przenieść do innego medium - a jeśli tak, to w jaki sposób ${ }^{28}$.

Gotowa czuję się tu, by postawić tezę świadomie nieco przerysowaną: sądzę s k i e g o (Falkiewicza przygoda duchowa. „Dialog” 1968, nr 9) na marginesie książki Mit Orestesa. Szkice o dramaturgii współczesnej A. F alki e w i c z a (Poznań 1967), będącej przecież alternatywną wykładnią bardzo podobnej problematyki. Podkreślając to, że autor nie zdecydował się na zasadnicze zmiany w przedrukowywanych tekstach (publikowanych w większości pierwotnie na łamach „Dialogu” w latach 1958-1960), Błoński zwracał uwagę na znaczącą ewolucję światopoglądową widoczną w tym projekcie. Na plan pierwszy wysuwał kilka zjawisk, które warto tu za nim zaakcentować. Po pierwsze, wypunktowywał charakterystyczne dla lat sześćdziesiątych XX w. istotne poszerzenie rozumienia eksperymentu teatralnego, który niejako ex post wchłonął poszukiwania pisarzy wczesnomodernistycznych, prekursorów awangardy (jak Artaud czy Witkacy). Po drugie, uwypuklał zwrot Falkiewicza ku temu wymiarowi interpretacji, w jakim szczególne znaczenie uzyskują ci autorzy, do których przyłożyć można koncepcje mistyczne, mistycyzujące bądź otwarcie religijne (Błoński wymieniał tu Becketta, Witkiewicza, Artauda i Geneta). Wreszcie - po trzecie - na plan pierwszy wysuwał potrzebę partycypacji. Pisał (ibidem, s. 99): „Ciekawsze jeszcze to, że zmieniając postawę krytyczną - na szlaku swej ewolucji przesuwa Falkiewicz ośrodek własnych zainteresowań: mianowicie od literatury bardziej go zaczyna interesować widowisko. Więc Teatr Okrucieństwa Artauda, więc Czysta Forma Witkacego, tak rozumiana, aby się raczej na scenie niż w tekście spełniała... Jest to najzupełniej logiczne: olśnienie będące "kresem najbardziej stromej przygody duchowej" przeżyć można najłatwiej w działaniu i uczestnictwie, a więc w sytuacji widza-aktora, którą niesie spektakl. Literatura stanowić będzie tylko punkt wyjścia, trampolinę... I tutaj Falkiewicz nie postępuje inaczej, niż zalecają najżywsze i najnowsze prądy teatralne”. Kierunek tej ewolucji byłby zatem w pewnym sensie odwrotny od tego, który dostrzegam u autora Zmiany warty: u Falkiewicza - od literatury do teatru (widowiska); u Błońskiego - od dramatu do pogłębionego rozumienia literatury, zmieniającego się w czasie. Owa sprzeczność jest jednak mocno pozorna: w obu bowiem wypadkach ruch opiera się na podobnym mechanizmie - od bycia biernym odbiorcą do wejścia w rolę kogoś, komu przypisany zostaje aktywizm, możliwość rzeczywistego przyczynienia się do przekształceń. 
mianowicie, że za zasadniczy wysiłek Błońskiego z lat sześćdziesiątych wolno uznać próbę przetransponowania kategorii Artauda - pierwotnie stosowanych w odniesieniu do widowiska - na teorię kultury, w szczególności zaś literatury. Interesują mnie tu przede wszystkim starania Błońskiego, by wykorzystać takiego rodzaju narzędzia do oceny literatury polskiej. Jeśli bowiem frankofoński eksperyment teatralny i dramaturgiczny waloryzował krytyk zasadniczo pozytywnie, to radykalizm polskich eksperymentatorów budził w nim bardziej dwuznaczne emocje. Spróbujmy prześledzić ten proces.

\section{Sen o literaturze i świat roztrzaskany}

Zobaczmy wpierw, jak - w zupełnie innym języku - formułował Błoński wspomniane oczekiwania. W roku 1963 odpowiadał na ogłoszoną na łamach „Życia Literackiego" ankietę zatytułowaną Ksiażka nienapisana, której celem było przebadanie krytycznoliterackich intuicji, projektów bądź też marzeń dotyczących rozwoju literatury polskiej. Autor Zmiany warty zaczynał - wydawałoby się - zachowawczo, niby dodając dalszy ciąg uwag do niej:

Jest w Polsce bardzo wiele nienapisanych książek: można nawet powiedzieć, że nasza literatura jest wciąż w znacznej mierze nienapisana. Ogrom i osobliwość doświadczenia dręczącego czy rozpalającego tę prowincję Europy domaga się ciagle wniosku, oceny czy po prostu pamięci: przygoda społeczności, związanej wspólnym losem, wspólną wędrówką przez przestrzeń i czas, doprasza się wciąż łaski u literatury, odpowiadającej głosem słabym i niepewnym na pytania, zacierane i zniekształcane przez mijające lata. Już od dawna ta sprzeczność między doświadczeniem a wyrazem, wnioskiem, światopoglądem doprowadza pisarzy do rozpaczy. [...] Tak więc nie bardzo wiem, jak rozumieć tytuł ankiety [...]. Czyżbym miał wskazywać na niewykorzystane tematy, a może nawet tematów szukać? [...]

[...] Takich „tematów” można wypisać ze sto [...]. Powstanie tak tablica współczesnych wątków powieściowych, niczym tablica pierwiastków Mendelejewa: mało będzie jednak z niej pożytku, ponieważ o wartości dzieła decyduje to, co włoży się w schemat: temat powieści jest zaledwie wyzwaniem, zaczepką, którą rzeczywistość rzuca myśli i wyobraźni ${ }^{29}$.

Wytyczał tym samym Błoński literaturze pewną drogę - opartą na konstruktywnym przepracowaniu doświadczenia historycznego, które uważał za unikatowe lecz uciekał przy tym od projektowania hipotetycznych możliwości jej rozwoju. Jak się wydaje, krytyka bawiło samo przeświadczenie, że o kulturze wolno myśleć w kategorii lekcji do odrobienia - stąd też może nieco protekcjonalna drwina $z$ katalogu tematów, które warto pisarzom teraz podyktować. Błoński w latach sześćdziesiątych XX wieku wciąż jeszcze pozostawał bardzo mocno uwikłany w retorykę sporów pokoleniowych i to naznaczyło część omawianego tekstu będącą bieżącym komentarzem: co z tego, że ludzie pióra maja tworzywo - niechby była nim i ich własna biografia, nawet pozbawiona wszelkiej barwności - skoro nie potrafią uczynić $z$ tego żadnego użytku? Z rozczarowania prozą tamtego czasu rodziła się zatem fantazja, która jest sednem cytowanej wypowiedzi - marzenie o Książce, realizujacej wszystkie najintymniejsze tęsknoty krytyka. Oddajmy mu głos: 
Byłaby więc ta Książka jakby Poematem, choćby dlatego, że współczesne, dwudziestowieczne dzieła, które największe na mnie zrobiły wrażenie - Czas utracony, sagę Faulknera, Proces czy Doktora Faustusa - odczuwam raczej jako poematy, wyzwolone $\mathrm{z}$ powieściowego skrępowania: precz $\mathrm{z}$ miałkim prawdopodobieństwem, rozsądnymi postaciami, precz z układaniem pikantnych intryżek! - i wydane na łup rozmaitym mitologicznym demonom, bogom i półbogom, których opisywaniem, jak wiadomo, zajmowała się pierwotnie epopeja. Z poematu miałaby również Książka - ambicję powiedzenia Wszystkiego (Faulkner mówi wszystko o Yoknatapawha [właśc. Yoknapatawpha], Proust wszystko o Marcelu, Mann wszystko o Niemczech) oraz ciemność, niezrozumiałość, rozjaśnianą tylko gdzieniegdzie błyskawicami całkowitego porozumienia $z$ autorem. [...] Nie dymnej zasłony chcę, ale bogactwa, które rzuca na kolana. [...] Tylko największe dzieła mają nieprzeniknioną oczywistość głazu: są jasne i tajemnicze równocześnie. Książka, o której myślę, mogłaby mieć powierzchnię gładką i łatwo przystępną, przynajmniej miejscami; skrywałaby jednak przepastne zagadki. Bo naprawdę jest tak (wbrew spłyciarzom i demagogom), że tylko to, czego w zupełności nie rozumiemy, co przyswajamy z trudem i oporem, budzi ciekawość i namiętność poznania. Chciałbym więc, by Książka wprawiała w rosnący niepokój, aby zmuszała do notatek na marginesach, do wykrzykników gniewu i znaków zapytania: aby - w pewnym momencie - wydała się niepojęta. Lecz energia i przenikliwa prawda fragmentów już zrozumianych - kazałaby jeszcze raz wrócić do początku, inaczej rozpatrywać sceny, które przed chwilą wydawały się oczywiste. Praca nad Książką byłaby, jeśli nie nieskończona, to na pewno długotrwała - ciągnęłaby się tygodniami i miesiącami. Być może, pisałbym o niej artykuły, a potem je odwoływał. Kto wie, czy nie powstałoby towarzystwo miłośników Książki, toczące maniackie spory o znaczenie rozdziałów, postaci, zdań czy nawet przecinków? ${ }^{30}$

W tym manifeście, balansującym na pograniczu powagi i jej zakwestionowania, kryje się szereg istotnych spostrzeżeń. W pierwszym odruchu potraktować ów fragment można jako formę ironicznego przypisu do motta do Zmiany warty. „Nic, co stało się całkowicie zrozumiałe, nie jest już nasze" - cytował w nim Błoński dwa lata wcześniej Prousta, domagając się tym samym takiej literatury, która wciąż chce przezwyciężać siebie samą, przekraczać własne ograniczenia. Zawodziło w tym zakresie pokolenie „Współczesności”, zbyt skrępowane tym, co w świetle rozpoznań krytyka można by nazwać nie małym już nawet, ale zminiaturyzowanym realizmem. Błoński marzył więc - pół serio, jak zachowawczo zastrzegał w przypisie - o literaturze, jaka potrafi stać się formą wszechogarniającej syntezy: nie tylko dlatego, że jej przedmiotem winna być Całość; przede wszystkim po to, by spiąć w jedno najdalej posuniętą nowoczesność rozwiązań literackich z głębokim przemyśleniem własnych fundamentów.

Domagał się zatem Błoński przecież w gruncie rzeczy literatury, która będzie w stanie zrewolucjonizować język epiki, zachowując w nim jednak pamięć jej pierwszej tradycji, także tej przywołującej dzikość i pierwotność sacrum. Tęsknił krytyk za realizmem wykazującym cechy antyrealistyczności - po to tylko, by uwypuklić własny arcyrealizm; za powieścią, w jakiej co chwilę dokonywałby się rozpad tradycyjnych struktur - po to tylko, by w finale odnawiała ona wszelkie możliwości tego gatunku. Błoński był zafascynowany światem ruchu i przeistoczeń, nieustannego wprowadzania w błąd i mylenia tropów; literatura, jakiej wizję snuł, miała żywić się życiem i być zarazem samowystarczalna - jej modelowy czytelnik winien wszak co chwila rozpoczynać od nowa i lekturę, i gest komentowania, za każdym razem odkrywając inne poziomy sensów i poruszeń. Bo też i dotykać miałaby owa Książka tego, co w odbiorcy najbardziej istotne i jakoś głębinowe - niekiedy poza- 
intelektualne - przez pierwotne niezrozumienie i niezgodę prowadząc do odkrycia prawdy.

Dodawał także Błoński natychmiast - jednocześnie wzmacniając polemiczny wymiar tekstu i wytrącając broń $\mathrm{z}$ ręki (wyobrażonym na razie tylko) adwersarzom - że książka, która mu się marzy, musiałaby bardzo mocno wiązać się z tym, co lokalne, że jej atutem winno być czerpanie $z$ tego, co miejscowe, przekształcanie prywatnych poruszeń twórczych, nie zaś gonienie za (formalnymi, ale i problemowymi) inspiracjami z zewnątrz ${ }^{31}$; tęsknił zatem Błoński za czymś, co wolno chyba nazwać intymnością uniwersalizacji. Od razu pytał też retorycznie, uściślając swój projekt:

Czyżbym więc o iłżeckim Panu Tadeuszu marzył albo o nowym Nad Warta, jak niegdyś Nad Niemnem było? O nie! Zawrotnie zawiła byłaby ta Książka. Przypuszczam, że łączyłaby w sobie, bądź chwytem kontrastu, bądź dzięki kontrapunktycznym rozwinięciom - rozmaite techniki wykształcone przez europejską powieść ostatnich dziesięcioleci. [...] Proponowałaby również techniki nowe, których, rzecz jasna, nawet pomyśleć nie mogę... [...] Możliwe, że demaskowałaby obie te techniki, każąc obu mówić coś przeciwnego, niż pierwotnie zamierzały. Obficie więc musiałaby stosować chwyty „złej wiary”: mówię „a”, aby powiedzieć „a,”. Lecz nie tu tkwić będzie największa trudność, spędzająca sen z powiek krytykom, nie tylko że „strumień świadomości” i „fenomenologiczny opis” zostaną użyte tak, by się wzajemnie uzupełniały i demaskowały, lecz jeszcze - zależnie od punktu widzenia, jaki przyjmie czytelnik - będą one relacjonowały bądź jednostkową historię, bądź jej mityczny odpowiednik, prawzór, objawiający się raz patetycznie, raz parodystycznie: inaczej mówiąc, Książka [...] byłaby jednocześnie oczyszczającą spowiedzią, uwznioślającym rytuałem i zimną obecnością świata ${ }^{32}$.

Śnił więc Błoński literaturę jeśli nie bezpośrednio nawet awangardową, to zdecydowanie nowoczesną, nie bojącą się eksperymentu; literaturę, która świeżość rozwiązań formalnych wykorzystuje do tego, by pokazać uwikłanie egzystencjalne jednostki, ale też i to, jak połączona jest ona $\mathrm{z}$ innymi - z szeregiem żyjących i umarłych, których losy stanowią matrycę kultury. Opisując to marzenie, Błoński nieprzypadkowo przywoływał wiele określeń o proweniencji religijnej, nie troszcząc się przy tym o zasady ortodoksji katolickiej. Jeśli Książka miała się mierzyć ze Wszyst-

31 Ironicznie kreśląc na marginesie tego szkicu swój wizerunek, niby to widziany z perspektywy co bardziej zachowawczej konkurencji, Błoński pisał: „mają mnie za nieuleczalnego snoba, wietrzącego wciąż za paryskimi nowinkami [...]” (ibidem). Znacząca jest tu i „paryskość”, i zamiłowanie do nowinek. Bo polemiczny wymiar tego tekstu dotyczy także rozumienia nowoczesności: zarówno u Błońskiego bowiem, jak i u innych przedstawicieli krakowskiej szkoły krytyki dostrzec można na przełomie lat pięćdziesiątych i sześćdziesiątych XX w. bardziej zniuansowany namysł nad tą problematyką, oparty przede wszystkim na zakwestionowaniu samego sensu pogoni za nowoczesnością rozumianą jako fetysz. Przenikliwie uwypuklał ten aspekt L. Fla s z en (Rekolekcje Nowoczesności. „Przegląd Kulturalny” 1957, nr 17. Przedruk w: Cyrograf. Kraków 1996, s. 313), postulując: „Nieważne, czy nowe - ważne, czy chwyta sytuacje współczesne. Nowość jest pochodna prawdy, a nie na odwrót”, a także dodając złośliwie: „Wydaje się, iż na Zachodzie awangarda jest czymś zwykłym i nie budzącym szoku, a jej prowodyrowie wyhodowali sobie tłuste zady akademików. Cudów nie ma; nowe, nienowe - sztuka musi iść z ciagłym postępem. A u nas Przyboś ciągle jest niezrozumiały i prędzej wielbłąd przejdzie przez ucho igielne, niźli on zdobędzie godne miejsce w szkolnych antologiach". Zakwestionowanie wartości samego nowatorstwa jest bardzo ważnym elementem rozumowania Błońskiego; próbuje on bowiem zbudować taki model myślenia o literaturze (i szerzej: o kulturze), który oparty będzie przede wszystkim na zachowaniu ciągłości: nie na całkowitym odrzuceniu, lecz na rewizji przeszłości i tradycji. 
kim i Wszystko w sobie pomieścić, to spowiedź mogła w niej wszak raz po raz przekształcać się w rytuał i odwrotnie, wchłaniając tym samym wielość potrzeb metafizycznych człowieka, dla których autor Zmiany warty różnych szukał imion.

Wyprzedzając uwagi ewentualnych oponentów, Błoński stanowczo podkreślał, że Książka nie byłaby tylko „intelektualnym ćwiczeniem” czy też „literacką zabawką"33, wprost przeciwnie - jeśli już - to kryłaby w sobie raczej wiele $z$ jakiejś ciemnej powagi. Igrając $z$ urokami enumeracji, krytyk wyliczał, co by to dzieło mogło w sobie pomieścić: wpisywał w nie „zadumę nad Pytaniami, które, stale w nas obecne, domagają się na próżno rozwagi i odpowiedzi”; liczył na namysł nad losem i zakresem ludzkiej wolności, na roztrząsanie relacji między obowiązkami względem siebie i względem zbiorowości, na sąd nad etyką i polityka, a także na rozważanie wiecznego sporu między Kulturą a Naturą, Naturą - a Historią. Dopowiadał: „Uchylam teraz tylko rąbka niezmierzonego bogactwa Książki, której rozdział, paragraf każdy, odkrywając nowe zagadnienie, pamiętałby zarazem o poprzednich [...]"34. I dodawał Błoński natychmiast, że nie o to chodzi, by Książka była zbeletryzowanym wykładem filozofii, choć i tę dyskusję umiałaby w siebie wchłonąć i sproblematyzować. Zdawałaby raczej sprawę $z$ tego, czym jest i może być erotyzm, potrafiłaby wreszcie - także przemyśleć znaczenie religii:

Jak miłość, tak religia - zaraz wytłumaczę, o co chodzi - ważną w Książce będzie grała rolę. Czyż bowiem nie ma racji Proust, mówiąc, że sztuka powstaje ze „współpracy ducha religijnego i miłości rzeczy”? I czy nie czas, by słowo „religia” rozumieć dostatecznie szeroko, jako ład nadrzędny i związek rzeczy przez nas zobaczony, upragniony każdemu? Jeśli tak, to niejednego ateusza uznamy za religijnego i przyznamy, że wszyscy chcemy być zbawieni, usprawiedliwieni, teraz lub na wieki wieków ${ }^{35}$.

Doprowadziwszy nas do tego punktu - jakoś paradoksalnie panteistycznego krytyk się nagle zatrzymał, marzenie o Książce było już bowiem nakreślone. Skala jej wymiaru religijnego i sposób jego charakteryzowania mogą w pierwszej chwili zastanawiać; kwestia ta staje się jednak bardziej zrozumiała, gdy przyjmiemy, że Błoński zakładał, iż w powieści to forma trzyma nas w ryzach, jest swoistym regulaminem rytuału. Jeżeli zechcemy się jej poddać i za nią aktywnie podażymy, to w finale powinno nas czekać poczucie porzadku wszechrzeczy; literatura nie powinna nigdy odbierać nadziei ocalenia, jej funkcja jest konsolidacja, nie zaś rozproszenie.

Marzenie Błońskiego nie dotyczy, oczywiście, pojedynczego dzieła, ale całości literatury. Wolno jednak, jak sądzę, odłożyć na bok tę świadomość i postawić pytanie: dlaczego to marzenie Błońskiego o literaturze totalnej zawodzi w starciu ze współczesną mu polską prozą? Czemu jej nowoczesność jest tak problematyczna, tak odmienna (i gorsza) od nowoczesności francuskiej? Co sprawia, że jakoś prawdziwsze okazuje się - wedle wskazań krytyka pochodzących $z$ omawianego okresu - 
bałaganiarstwo rozwiązań Stanisława Ignacego Witkiewicza od subtelnych konstrukcji intelektualnych, nad którymi pracuja w domowym zaciszu nie tak znowu już młodzi awangardyści? Dość prześledzić zjawisko na jednym przykładzie - będzie nim pisarstwo Leopolda Buczkowskiego, które Błoński komentował kilkakrotnie, po drodze drastycznie zmieniajac zdanie. Przykład ten nie jest przypadkowy: nakreślony przed chwila projekt Błońskiego powstał wyraźnie pod wpływem twórczości Buczkowskiego, wydawać by się nawet mogło, że to ona stanowiła najpełniejszą z możliwych realizacji wymienionych postulatów.

Powitał krytyk ową twórczość - zaczynając od zrecenzowania Czarnego potoku - zrazu dość życzliwie, choć i nieco zachowawczo. Jakby nie do końca miał do niej dostęp i nie darzył jej na wstępie przesadnym zaufaniem. „Nie można Czarnego potoku opowiedzieć" - stwierdzał w pierwszym zdaniu omówienia opublikowanego na łamach „Nowej Kultury” z 1955 roku $^{36}$, a przecież dalej próbował tę rozbita fabułę jakoś zrelacjonować i nawet jego problematyzacja (będąca już interpretacja) opierała się na wyciaganiu kolejnych niteczek streszczenia. To nie literatura - przekonywał znowu Błoński - lecz świadectwo wykraczające poza literaturę i jej możliwości; to proza niosąca ze sobą szereg komplikacji, widocznych już choćby na poziomie jej zanikającego sensu:

Zapis ten daje tekst zatarty, niezrozumiały; słowa na pozór jasne, których związek wydaje się nierealny. Znaczenie ulatnia się z nich z latami, w miarę jak niknie punkt odniesienia, wspólny dla pisarza i czytelnika ${ }^{37}$.

Czarny potok to zagadka - nie sposób bowiem ocenić, czy eksperymentalność tej książki wciąż jeszcze jest zaletą ${ }^{38}$. Buczkowski - pokazuje Błoński - próbuje

J. Bło ń s k i, Droga zabójców i droga prawdy. „Nowa Kultura” 1955, nr 28, s. 6.

Ibidem.

W tym kontekście (dyskusji nad znaczeniem i charakterem eksperymentu w prozie awangardowej) szczególnie istotne wydaje mi się przypomnienie zastrzeżeń A. Sandauera, którego trudno posądzić o konserwatyzm i fundamentalną niechęć względem tego typu tendencji. Komentując pozytywne przyjęcie Czarnego potoku, stwierdzał on kategorycznie (Pod czy ponad. „Nowa Kultura” 1960, nr 8, s. 3): „działają tu - zamiast jednej - aż trzy taryfy ulgowe. Utwór, którego wydanie w minionym okresie napotykało trudności, który opisuje zagładę Żydów, który pretenduje wreszcie do unowocześnienia techniki pisarskiej, może - bez względu na poziom - liczyć w krytyce naszej na kryteria zniżkowe”. S anda u er koncentrował się na nieścisłościach i niedorzecznościach, jakie dostrzegał w prozie Buczkowskiego, uważał, że jej kariera napędzona została przede wszystkim przez oczekiwania komentatorów - cytowany tekst miał w sobie wiele z zacięcia pamfletowego, tak właściwego zbiorowi Bez taryfy ulgowej, nic więc dziwnego, że piszący wypominał w nim wprost: „Chodzi przecie o to, aby móc uczynić gorzki wyrzut: "Oto, jakie arcydzieła tępiliście!" Ergo - Czarny potok powini en być arcydziełem; jeżeli zaś nim nie jest, to - tym gorzej dla rzeczywistości" (ibidem). Nowoczesność tej prozy stawiał S a n d a u e r wyraźnie pod znakiem zapytania, a niewykluczone, iż nawet mocniej: dostrzegał w niej coś na kształt imitacji. Podważał bowiem jedno z podstawowych założeń artystycznych Buczkowskiego, podkreślał, że fantasmagoryczny wymiar doświadczenia wojennego nie może zostać oddany w sposób paradoksalnie mimetyczny - poprzez rozbicie narracji, jej „majaczliwy i nieudolny” charakter (ibidem). Prowadziło to S a n d a u e r a do konkluzji, w której dowodził on, że Czarny potok nie dorasta do swoich ambicji; okazuje się poniekąd podwójnie nieudany - zarówno jako świadectwo, jak i jako próba prozy nowoczesnej. Publicysta puentował wypowiedź w sposób, który częściowo bliski będzie późniejszym refleksjom Błońskiego (czynionym na marginesie Pierwszej świetności): Czarny potok odbiega od prozy realistycznej „nie dlatego, że nią być nie chce, ale że - nie potrafi, że autor [...] po prostu nie panuje nad 
przełamać ograniczenia odbiorcy, nauczyć go zupełnie odmiennego porządku lektury. Krytyk pisze o tym autorze:

wcale na tym [mu] nie zależy, aby czytelnik rozumiał kolejność i logikę zdarzeń. A nawet - w pewnym sensie - [Buczkowski] chce, aby [odbiorca] jej nie rozumiał. Gdyby bowiem owe zdarzenia [autor] ustawiał logicznie, „zrozumiale”, czytelnik znalazłby się na zewnątrz tragedii, patrzyłby na nią tak, jak widz patrzy na scenę. Widz wie więcej niż bohaterowie dramatu. A Buczkowski pragnie go zmusić, aby wiedział tyle, co oni. Nie, aby rozumiał mechanizm, ale by ws półprze żywał katastrofę. Stąd głosy: „Buczkowski torturuje czytelnika, to histeria wyobraźni!” - miałyby rację, gdyby Buczkowski pragnął uchwycić ton epoki, gdyby losy Szabasowej chciał - opowiedzieć. A on nie chce. Pragnie je - odtworzyć ${ }^{39}$.

Proszę sobie w tym miejscu przypomnieć uwagi dotyczące Artauda i formuły partycypacji - tak życzliwie powitanej przez Błońskiego; proszę przywołać w pamięci ten fragment manifestu krytyka mówiący o literaturze i rytuale. Gdy autor Czarnego potoku chciał swego odbiorcę przeprowadzić przez analogiczny proces, napotykał opór. Bo zacytowany przed chwila akapit jest w tekście Błońskiego próba wyjaśnienia tylko, a nie - zapisem entuzjazmu. Jest próbą przeniknięcia reguł, które rządzą tą prozą: jeśli zaś okazuje się ona tak bardzo poszarpana narracyjnie, to jej sensu szukać należy na innym poziomie. Błoński do takiego rozumienia literatury, jakie proponuje w tym wypadku Buczkowski, zdaje się powoli dorastać - tu jeszcze (paradoksalnie) wygląda ono raczej na atrakcyjna propozycję intelektualną, a nie na coś, co by zachęcało do uczestnictwa. Stąd zapewne Błoński - starając się znaleźć jakieś wytłumaczenie dla swego podejścia - chce ten poziom eksperymentalności niejako obniżyć: wskazuje, że omawiana proza oparta jest tak naprawdę na głębokim przywiązaniu do realizmu, bo tylko kurczowe trzymanie się faktów i realiów może chronić piszącego, w żadnym wypadku nie ma tu miejsca na kłamstwo $^{40}$.

materiałem. W oczach krytyków, spragnionych odkrywczego spojrzenia na okupację i przekonanych, że majaki oddawać należy techniką majaczliwa, ta jego nieudolność może ujść za niezwykle śmiały eksperyment. Rzecz jednak w tym, że - przedstawiając koszmar - artysta musi w jakiś sposób być poza nim, poddawać mu się, ale i panować nad nim, pogodzić trzeźwość z pijaństwem” (ibidem). Przywołuję Sandauera nie bez powodu - sądzę bowiem, że rozumienie nowoczesności w ujęciu Błońskiego (lecz także innych przedstawicieli krakowskiej szkoły krytyki) wyraźnie kształtowało się w pewnym (polemicznym) dialogu z koncepcjami autora zbioru Bez taryfy ulgowej. Bodaj najważniejszym tematem dyskusji było sytuowanie i pojmowanie znaczenia przedwojennej awangardy. U Sandauera podlegała ona swoistej absolutyzacji, okazywała się rodzajem matrycy, do której chciał on przyrównywać późniejsze osiagnięcia (na ogół wypadało to na ich niekorzyść - by przypomnieć tylko jeden, wyraźnie pogardliwy termin, jakim zwykł się on posługiwać: „postawangarda”, zabarwiony lekceważeniem). U Błońskiego te mocne cięcia między literaturą przed- i powojenną właściwie nie występują. Kredyt zaufania dawany aktualnie powstającej twórczości też jest znacznie wyższy, krytyk nie rozumie jej jako nieudolnej kopii. I choć zarówno Sandauer, jak i Błoński będą tą nową twórczością rozczarowani, to do jej oceny zastosują inne argumenty: pierwszy chętniej położy nacisk na używanie klisz i zamiłowanie do tandety, drugi - na brak autentyzmu, względem czego technika literacka jest wtórna. Zob. też uwagi G. W oł o w c a (Nowocześni w PRL. Przyboś $i$ Sandauer. Wrocław 1999, zwłaszcza część W obronie zdobyczy), dotyczące kształtowania się stanowiska Sandauera po Październiku, oraz komentarz M. Pi etr zaka (Krytyka literacka wobec pokolenia „Wspótczesności”. Warszawa 2007), pokazujący, w jaki sposób Błoński i A. Kijowski odnosili się do cyklu Bez taryfy ulgowej. 
Wydaje się jednak, że najbardziej niepokoiła Błońskiego ambiwalencja etyczna omawianej książki:

[...] Czarny potok - i to jest największą zasługą Buczkowskiego - nie jest tylko dokumentem, relacją, lamentem. Dokument zbiega się (i to jest u Buczkowskiego nowe) w konflikt moralny: konflikt między uczciwością a skutecznością, jak w każdej walce, a zwłaszcza takiej. Nie inny niż ów zawarty w pytaniu Dostojewskiego, czy wolno by było za cenę śmierci jednego dziecka zlikwidować całe cierpienie całego świata. Są sytuacje, w których przecząca odpowiedź na to pytanie wydaje się zbrodnią. W codziennym życiu wymija się je półśrodkiem lub cierpliwością, tu jednak wciela się krańcowość. Czy można, czy wolno zachować czyste ręce? Czy zdjać z palca zamordowanej dziewczyny pierścionek, skoro dałoby się może przechować zań małego Dudi? Buczkowski wie, że skuteczność zawsze zwycięża. Nie ma rady, w tym właśnie jest nieszczęście. Ale trzeba się bronić przed dwuznacznością moralną: umie to nie tylko ksiądz Bańczycki, ale także lekarz Chaim i robotnik Kuba Szerucki. Bańczyckiego wieszają hitlerowcy, Szerucki zaginął (to znaczy zginą), Chaim zostaje przy bezbronnych, wybiera męczeństwo. Inni wybierają skuteczność. Kto odważy się rzucić na nich kamieniem? Wybierają z rozdartym sercem.

Nie wiem, czy Czarny potok jest dobrą powieścią. Ale cóż to nas obchodzi? Wstrząsa prawdą to wystarczy $^{41}$.

3

Wracał Błoński do Buczkowskiego po trzech latach, w 1958 roku, pisząc równocześnie o Czarnym potoku i o Doryckim krużganku. Recenzja ta miała już zupełnie inny

trwającej wówczas kolejnej fazy rozważań o realizmie, ściśle powiązanej z namysłem nad sztuką (później także literatura) nowoczesną. Głos Błońskiego ukazał się w „Nowej Kulturze”, która stosunkowo szybko dołączyła do żywej debaty na temat nowoczesności, prowadzonej już od początku 1955 r. na łamach „Przeglądu Kulturalnego”, a zainicjowanej wystapieniem J. Ć wi e r t n i zatytułowanym $O$ smaku destylowanej wody, o metodzie uchylania drzwi i jeszcze o kilku sprawach natury artystycznej (nr 11). Stawiając mocną tezę: „Należy chyba powiedzieć sobie, że nie ma deformacji realistycznej lub nierealistycznej ani żadnych form nierealistycznych, gdyż realizm to nie jest sprawa jakiejś konkretnej formy, ale sprawa widzenia rzeczywistości. Te same formy artystycznej deformacji w sztuce raz mogą służyć prawdzie, a drugi raz fałszowi obrazu świata. Decyduje o tym powstałe, konkretne dzieło - zrealizowane zamierzenie twórcy" (ibidem, s. 8), Ćwiertnia jednocześnie niezwykle celnie wypunktowywał bardzo charakterystyczną praktykę retoryczną, uskutecznianą przez wielu komentatorów chcących „przemycać” sztukę bądź literaturę awangardową. Zwracał wszak uwagę na swoiste rozbrajanie jej radykalnego potencjału przez dodanie zabezpieczającego epitetu: „realistyczna”. Spostrzeżenia Błońskiego bez wattpienia oparte są, przynajmniej częściowo, na podobnym mechanizmie językowym, ale - jak sądzę - nie wynika to tylko z potrzeby asekuracji i znalezienia dla siebie miejsca w odgórnie narzuconej ramie dyskursywnej. Te zabiegi nie sprowadzają się bowiem u Błońskiego wyłącznie do wywalczenia pola dla twórczości Buczkowskiego, są raczej zapisem wątpliwości samego krytyka - który chce się za eksperymentem opowiedzieć, nie czuje się jednak doń w całości przekonany. To zjawisko - skłonna byłabym je nazwać paradoksem warunkowej akceptacji - jest zresztą dla krytyki Błońskiego w tym czasie dość typowe: wystarczy wspomnieć pozytywny wymiar Zmiany warty, zawierającej więcej nadziei na przyszłość niż satysfakcji z dotychczasowych spełnień literackich. W tak płynnym - rozszerzającym - rozumieniu realizmu można również dostrzec wpływ koncepcji K. Wy ki: argumentacja Błońskiego przypomina skróconą logikę wywodu prowadzonego w szkicu Tragiczność, drwina i realizm („Twórczość” 1945, nr 3). Zob. omówienia dyskusji o nowoczesności w krytyce i publicystyce okołopaździernikowej: M. Kis i el, Zmiana. Z problemów świadomości literackiej przełomu 1955-1959 w Polsce. Katowice 1999 (zwłaszcza podrozdział Między realizmem a awangarda). - J. G a l a n t, Odmiany wolności. Publicystyka, krytyka i literatura polskiego Października. Poznań 2010 (zwłaszcza rozdział Nowoczesność - normalność - wolność).

41 Błoń s ki, Droga zabójców i droga prawdy, s. 6. 
wydźwięk: była zdecydowanie Buczkowskiemu życzliwa, do tego stopnia, że szereg uwag z poprzedniego tekstu można by uznać za wynik przycinania własnej opinii $\mathrm{w}$ obawie przed starciem $\mathrm{z}$ cenzurą. $\mathrm{W}$ argumentację Błońskiego od początku bardzo wyraźnie wplecione było wartościowanie - jeśli Czarny potok jawił się jeszcze jako zapowiedź, to Dorycki krużganek jest formą spełnienia; idzie dalej na płaszczyźnie formalnej (odchodzi od „historii” na rzecz uchwycenia „sytuacji”) i krytyk mówi jasno: „Buczkowski [...] odwraca tradycyjną technikę powieści i proponuje arcyciekawy eksperyment, może najbardziej ryzykowny, jaki zdarzyło nam się czytać po wojnie" 42 .

Na czym ta oryginalność Buczkowskiego miałaby się opierać? Na momencie uchwycenia końca świata - to na pewno. Ale też na zdolności do narracyjnego oddania atmosfery apokalipsy. Podkreślam ów aspekt, bo z czasem zacznie on w Pierwszej świetności - Błońskiego mierzić. W Doryckim krużganku zaś eksperyment jest oceniany pozytywnie - nie ze względu na zachwyt nad efektem końcowym, lecz z racji uprzywilejowania samego podjęcia próby. Błoński komentuje:

Słowem - tak narrator, jak postacie poruszają się wśród faktów, odartych ze swego pełnego znaczenia, wśród faktów - rzeczywiście nagich. Technikę powieści Buczkowskiego można by - pochopnie! uznać za antyrealistyczną. Widać tu jednak wyraźnie, jak to, co uchodzi za „realistyczne”, jest w istocie tylko tradycyjne. „Antyrealizm” wynika tu bowiem z troski o „większy realizm”, wsteczne konstrukcje - ze ściślejszego rozważania, jak pojmujemy wypadki: odarcie (chwilowe) faktów ze znaczeń - ze zbadania sytuacji narratora. Co nie znaczy, aby wydarzenia Doryckiego krużganka nie układały się w całość do pojęcia. Owszem, można ustalić wzajemne stosunki postaci, można przyszpilić prawdopodobną chronologię fabuły. Tyle że zniknęłaby wówczas - sztuka Buczkowskiego ${ }^{43}$.

Czytając ten tekst, odnosi się jednak również wrażenie, że Błoński nieco na siłę chce w Dorycki krużganek wpisać istotne dla siebie wymiary. Zdaje sie przecież mówić: Buczkowski wciąż próbuje nas przeprowadzić przez proces rozpadu świata, raz po raz wymusza na nas uczestnictwo, stawia nas po stronie ofiar i po stronie katów, nie pozwala odwrócić oczu. Piętrząc przed czytelnikiem trudności formalne, dodatkowo popycha do dalszego wysiłku - zderzenie $z$ ostateczną katastrofą nie może być łatwe, załamuje ona nie tylko potencjał poznawczy bezpośrednich uczestników, ale i nas - po latach próbujących (z założenia bezskutecznie) odnajdywać w niej przynajmniej okruchy sensu i logiki. I choć - nadal rekonstruuję tok argumentacji Błońskiego - nie zawsze Buczkowskiemu udaje się zachować całkowitą konsekwencję, choć niekiedy razić mogą niektóre jego nieporadności, to sama tak pomyślana próba budzić musi respekt. Znamienne jest tu zresztą widoczne w obserwacjach krytyka przejście od literatury świadectwa do „nad-realizmu”, rozumianego nie jako kierunek literacki, ale jako forma absolutyzacji możliwości poznania realistycznego, którą w pewnym sensie wolno by w takim wypadku uznać za ekwiwalent poszukiwań Gombrowicza.

A jednak - istnieje coś, co Błońskiego niepokoi, coś poważniejszego niż wspomniane nieporadności. Ten świat roztrzaskany jest bowiem - światem bez wartości, światem, który stracił wiare w jakikolwiek przedustawny porządek. Jest - przynajmniej w Czarnym potoku czytanym przez Błońskiego - chaosem, magmą zdarzeń; rzeczywistością, w jakiej postacie marzą już tylko o fizycznym przeżyciu, a nie - 
o zbawieniu. Nie złorzeczą Bogu, Boga bowiem w ich świecie nie ma. Krytykowi brakuje zaś wciąż jakiejś nadrzędnej racji, szuka on - uzasadnienia. I po lekturze Doryckiego krużganka niby znajduje:

Wartością, w imię której walczą bohaterowie Buczkowskiego, jest Dom - ten krąg moralno-obyczajowy, w jakim się urodzili i wychowali. Humanizm tu wynika z dawnego życia szczupłej, lecz moralnie płodnej społeczności. Ową tradycję zaznacza Buczkowski, nasycając swą relację prowincjonalizmami, bajkowym wspomnieniem, porzekadłem, przysłowiem. $Z$ niej bohaterowie czerpią wiarę i siłę. „W tym miejscu - czytamy - ujrzałem pierwszy raz węzeł dławiący i zaraz zacząłem go rozwiązywać i stawać się wolnym. Wszechświat nie jest martwy i czartowski - jest boski i naszych rodziców. I na nowo zacząłem siebie szanować i używać średnich miar”. Te „średnie miary”, przejęte od rodziców, zachowane w małym światku, symbolizują skromną i dyskretną, ale jakże skuteczną, etyczną tradycję ludzkości - demaskując głęboki fałsz kulturalny, jakiego przedstawicielami byli Gall czy Osnabrick ${ }^{44}$.

Racja ta jednak nie chce wybrzmieć przekonywająco, jest jakoś dziwnie kulawa. Błoński wykorzystuje tu przy tym metodę, którą nazwać by można recyklingiem literackim; metodę w ogóle chętnie przezeń stosowaną - w kolejnych odsłonach przedrukowywał on wcześniejsze teksty, dokonując zarazem ich znaczacej rekontekstualizacji. Zabieg ten nie dotyczył tylko całych szkiców, włączanych do następnych książek, rozgrywał się także na poziomie niewielkich fragmentów, które były wchłaniane przez późniejsze artykuły, wybrzmiewając w nich już inaczej. Przykładowo, fragmenty recenzji Czarnego potoku z „Nowej Kultury” zdecydował się Błoński wpleść do dłuższego komentarza $z$ „Przeglądu Kulturalnego”, wiążąc refleksje o tej powieści z namysłem nad Doryckim krużgankiem. Zapewne głównie po to, by raz jeszcze uniknąć jałowego przytaczania informacji wcześniej podanych; bezpośrednie powtórzenie tych wyimków musiało być wszakże formą aprobaty - oznaczało tyle, że autor nie zmienił zdania w omawianych kwestiach.

$Z$ jednym, ale bardzo istotnym w tym wypadku wyjątkiem. W cytowanym przez siebie fragmencie zakończenia Błoński dopisał słowo: „nie” - krótkie, lecz zupełnie przekształcające sens całej wypowiedzi. Recenzja $z$ „Nowej Kultury” kończyła się stwierdzeniem, że w świecie Buczkowskiego zawsze skuteczność zwycięży nad uczciwością; to właśnie ono zostało po latach mocno złagodzone dzięki tej zmianie. Na pierwszy rzut oka może się wydawać, że to poprawka czysto kosmetyczna, ma ona jednak tak naprawdę charakter fundamentalny, pozwala bowiem krytykowi opowiedzieć się po stronie eksperymentu, w którym odnajduje on wymiar pozytywny. Potencjał etyczny literatury okazuje się tutaj decydujący: w świecie rozsypanych reguł gwarantuje ułamek sensu.

\section{Pod koniec maja 1967 Stanisław Lem donosił Mrożkowi:}

Wyszła teraz Pierwsza świetność Buczkowskiego Leopolda, chwalona przez wszystkich właściwie (Mętrak, Bereza, Hanna Kirchner), ale zapewniam Cię, że jest to szczególny rodzaj zjawiska - gdyż powieść owa przedstawia klinicznie czysty casus schizofrenii, bez żadnych mówię przenośni, metafor, to naprawdę jest płód choroby umysłowej, kompletny rozpad, ale to kompletny! Nikt z krytyków nic nie rozumiał [...], bo do rozumienia w chaosie tym nic doprawdy nie ma, reakcje ich zaś są funkcja globalnej sytuacji literatury i światowej, i naszej (rozpadu kryteriów, mętności semantycznej, mgły powszech- 
nej, poszukiwań nadto rozpacznych, w których zdarza się, że normalni naśladują szaleństwa wszelakie). Casus bardzo drażliwy. Janek [Błoński] pisać o tej książce ze zrozumiałych powodów nie chce (w końcu stawiać diagnozę tego rodzaju jest rzeczą psychiatrów raczej - krytyka nie ma tu nic do roboty). Problem właściwy tkwi w owym nieporozumieniu (więcej niż żenującym), co sprawiło pochwał chóry. Gdyż daje się teraz kredyt nadzwyczajny całkiem i bezlimitowy niezrozumiałości tout court - po prostu carte blanche się wystawia i oto wstydliwe konsekwencje! $!^{45}$

Powody milczenia Błońskiego - w tamtej chwili jasne dla obu korespondentów dziś już wcale nie są takie przejrzyste. Lem podsuwa, co prawda, uzasadnienie, ale nie wydaje się ono tłumaczyć wszystkiego: problem Błońskiego $z$ nową powieścią Buczkowskiego nie pozwala się bowiem zredukować jedynie do obawy, że autor tejże popadł w szaleństwo (swoją drogą - szaleństwo to raczej by pewnie pociagało autora Zmiany warty), nie mieści się także w przeświadczeniu, iż krytyka zupełnie straciła już miarę, całkowicie afirmując i wywyższając niejasność. „Klinicznie czysty casus schizofrenii” - pisze zirytowany Lem. A Błoński? Skomentuje przecież Pierwsza świetność w tekście utrzymanym w tonie prawie pamfletowym - wymierzonym jednak nie tyle w autora powieści, ile w komentatorów, którzy się nią bezrozumnie zachłysnęli ${ }^{46}$. $Z$ pozoru większość owych uwag będzie dotyczyła techné literackiej. Błoński przekonuje czytelnika, iż spodziewał się, że kolejne książki Buczkowskiego rozjaśniać będą naturę jego eksperymentu pisarskiego, ale tak się nie dzieje. Eksperyment ów postępuje i coraz trudniej odczytać bądź odnaleźć jego uzasadnienie. Gra kontrolowanej anarchii - tego szukał wcześniej Błoński u Artauda:

Choć poruszona anarchicznymi mocami, twórczość musi wyrażać się przez określony układ form, choćby te formy były umowne, zaskakujące, zupełnie niezgodne z potocznym doświadczeniem, wreszcie zaś - zmienne ${ }^{47}$.

O powieści Buczkowskiego krytyk pisał zaś, że nic nie trzyma jej w ryzach można powiedzieć (syntezując argumenty pojawiające się także w tekstach innych dość sceptycznie nastawionych komentatorów), że przekraczając formy, wykrzywiając je i parodiując, autor nawet nie stara się stworzyć ramy ostatecznej, scalającej. Płynność - dopowiada już sam Błoński - staje się tu więc fetyszem: nic nie ma ustalonego kształtu; znika zarówno porządek chronologii, jak i jakikolwiek porządek tożsamości. Wbrew jednak zamiarom piszącego - sugeruje krytyk - nie powstaje w ten sposób kondensat doświadczenia, lecz tylko coś na kształt jego niepokojącej atrapy: tak pomyślany tekst osiaga poziom całkowitej nieczytelności; nie ma dostępu do dzieła, którego poetyka oparta jest na odrzuceniu wszelkich możliwych reguł. Te - mówi Błoński, odnosząc się do przykładu francuskiej nowej powieści - mogą być dowolnie skomplikowane, jednak muszą istnieć. Dopowiedzmy:

S. Le m, list do S. Mrożka, z 28 V 1967. W: S. Le m, S. M roż e k, Listy 1956-1978. Kraków 2011, s. 630.

46 Przypomnieć należy - dla równowagi - w tym miejscu, że kolejne książki Buczkowskiego budziły u krytyki raczej narastający dystans niż zachwyt, a logika rozumowania wielu komentatorów zbieżna pozostaje $\mathrm{z}$ myśleniem Błońskiego: zarzucano Buczkowskiemu przesadny eksperymentalizm i nihilizm. Zob. szczegółowe omówienie recepcji tej twórczości: S. B u ryła, Proza Leopolda Buczkowskiego - niepokoje i obawy krytyków. W: Prawda mitu i literatury. O pisarstwie Tadeusza Borowskiego i Leopolda Buczkowskiego. Kraków 2003. 
trzymają bowiem w ryzach nie tylko samą powieść, ale i świat, ukorzeniaja go i zabezpieczają; nie bez powodu u Błońskiego tak blisko od scalenia - do ocalenia.

Stąd zaskakujące na pierwszy rzut oka przejście: uwagi o charakterze genologicznym odsyłają w tym wypadku zupełnie jednoznacznie do sfery szeroko rozumianej ontologii; a krytyk, polemizujac $z$ pozoru $z$ propozycja interpretacyjna Kirchner, mimochodem zdaje się sugerować, że nie do zaakceptowania jest dla niego demontaż świata tak daleko posunięty, by nie do pomyślenia było potem złożenie $z$ jego elementów jakiejkolwiek nowej całości. W zadziwiający sposób poetyka normatywna przekształca się więc w rodzaj instrukcji (zarówno literatury, jak i życia) - czytając Błońskiego, zaczynamy mieć wrażenie, że chciałby on niejako oswoić Buczkowskiego, przeciągając go na stronę pisarzy rozumiejących eksperyment w duchu praktyk OuLiPo. Bo choć i one nie mogły być autorowi Zmiany warty przesadnie bliskie, to jednak - pozostawały zrozumiałe, nie rozsadzały porządku wartości ${ }^{48}$. Były - eksperymentem kontrolowanym.

Krytyk kończył:

Pojmuję, co zwiodło Berezę i innych: w Pierwszej świetności jest sporo pięknych zd ań. Są tam także - aczkolwiek rzadsze - uderzające s c e n y. Pisarz zgubiony nie przestaje być pisarzem i najbardziej szalony chwyt kompozycyjny (lub jego brak) nie poraża umiejętności widzenia i nazywania świata. Inaczej mówiąc, krytycy czytali Pierwsza świetność jak poemat, którego się najpierw nie rozumie: zachwycając się luźnymi obrazami. Ale poza to wrażenie nie wyszli [...]. Logiką poematu może być tylko spoistość, nawrotność czy przemienność obrazów i skojarzeń. Jeśli jednak uznać Pierwsza świetność

Myślę, że za bardzo znamienne można uznać określenie użyte przez Błońskiego w nie opublikowanym tekście $z$ lat osiemdziesiątych XX wieku. Kreśląc ewolucje prozy powojennej, pisał krytyk w nawiązaniu do literatury obozowej (archiwum Instytutu Literackiego w Maisons-Laffitte. Podkreśl. M. Sz.): „Człowiek przestał być podmiotem swego losu. Ponosi jednak - zasłużenie? niezasłużenie? - odpowiedzialność za znieprawienie historii. Czy jego winą nie jest to, że przeżył? Nieposkromiona żywotność bohatera opowiadań Borowskiego dowodzi nieograniczonej plastyczności człowieka, którego kształtują naprawdę okoliczności, nie lekcje cnoty i mądrości. Rozpacz i frustracje kazały oskarżać europejską tradycję wychowawczą; prowadziły tak do poetyki lodowatego cynizmu albo sarkastycznego współczucia. Aby to świadectwo było pełne, musiało pokazać rozpryśnięcie moralności, naiwnej może, ale takiej, co pomaga żyć... i czasem nawet umierać. Musiało mówić o metafizyce eksperymentu, którym było zdeptanie cywilizacji w obozach koncentracyjnych. Musiało wyrazić się rozsypaniem wzorców językowych, choćby prozaizacją liryki, zapoczątkowaną przez Różewicza. Ale było to już więcej, niż mogli strawić teoretycy (czy terroretycy) socrealizmu, którzy już w 1948 zawładnęli literaturą". Chociaż eksperyment rozumie tu Błoński, oczywiście, zupełnie inaczej, to zbitka jest, moim zdaniem, znaczaca: „metafizyka eksperymentu” stanowi chyba w myśleniu krytyka pojęcie całościowe; to wychylenie ku czemuś, co większe od nas, aż do granic radykalne, uzasadnia dopiero sens eksperymentu literackiego. Wydaje się zresztą, że istotne są tu słowa krytyka $z$ jednego ze stosunkowo późnych wywiadów, przeprowadzonego przez K. i S. Chwinów w 1991 roku. J. Błoński wypowiadał się wówczas raz jeszcze na temat twórczości Borowskiego, zestawiając ją jednak z tekstami G. Herlinga-Grudzińskiego. Stwierdzał (Najlepsze lata. Z Janem Błońskim rozmawiaja Krystyna i Stefan Chwinowie. W: Błoński przekorny, s. 423): „inaczej przedstawiają się reakcje więźniów sowieckiego gułagu i więźniów obozów niemieckich. Jakby ci pierwsi trzymali się lepiej, lepiej bronili przed wewnętrznym spustoszeniem i zniewoleniem". W dokonanej przez Błońskiego charakterystyce pisarstwa Borowskiego można odnaleźć zaniepokojenie ciemnością, krańcowością owego doświadczenia, które pozbawione jest jakiegokolwiek wymiaru pozytywnego. Jak sądzę, to dokładnie ten sam rodzaj niepokoju, jaki odsuwał krytyka od pisarstwa Buczkowskiego i sprawiał, że autor Zmiany warty opowiadał się raczej za modelem literackim Herlinga-Grudzińskiego, w sytuacji doświadczenia granicznego zostawiającym wciąż miejsce na okruchy nadziei. 
za poemat, to przyznać także trzeba, że - niezmiernie on słaby: albowiem zdania znaczące, nasycone liryczną treścią, zgubione zostały w morzu poprawnej co najwyżej prozy. [...] Jakkolwiek więc Pierwsza świetność rozpatrywać, zawsze okaże się ona pomyłką i ślepą uliczką; i jakkolwiek rozumieć jej recenzentów, zawsze wydają się [oni] zabłąkani na bezdrożach ${ }^{49}$.

Dziwny i paradoksalny finał. Bo rozprawienie się Błońskiego z Buczkowskim i jego recenzentami było przecież zarazem przekreśleniem własnych oczekiwań czy postulatów; stawało się formą korekty do wcześniejszego projektu wywodzonego z pism Artauda. Fakt ten ulega obnażeniu już przez używany przez Błońskiego język i - jeśli wolno to tak nazwać - zespół przyrównań: przypomnijmy, że nie tak dawno to sam krytyk marzył o Książce bliskiej poematowi; rozbitej na sceny, które - poddane uważnej lekturze - ostatecznie będą na nowo oświetlać się nawzajem. Żądał też Błoński niezrozumiałości, choć poskromionej, bo tylko ona może być wyzwaniem. W recenzji Pierwszej świetności nagle kapitulował - i ta kapitulacja nie dotyczyła wyłącznie powieści Buczkowskiego.

W dużej mierze Błoński w omawianym tekście wykładał na nowo własne oczekiwania - koncentrując się tym razem na „spoistości, nawrotności czy przemienności obrazów i skojarzeń”, które zdają się rządzić czymś więcej niż tylko „logiką poematu". Sa bowiem spoiwem ładu (a może nawet ów ład uosabiaja), jak zaś widzieliśmy już wcześniej - wiara w istnienie tego ładu bądź co najmniej tęsknota za nim była dla Błońskiego równoznaczna $z$ nowoczesnym rozumieniem literatury, opartej na dominancie religijnej czy metafizycznej. Ale zapewne i z czymś więcej: $z$ rozumieniem literatury jako takiej; bo przekroczenie wspomnianego ładu oznacza wyjście poza literature - czy to w stronę świadectwa (jak w wypadku Czarnego potoku), czy anihilacji (jak w Pierwszej świetności). Stąd zapewne tak ostra (jak na tego krytyka) puenta owej recenzji i jej kategoryczność: dzieło Buczkowskiego jest pomyłką; entuzjazm komentatorów pozostaje zaś tak szkodliwy, bo stanowi przyzwolenie na nihilizm, wyraz aprobaty dla wprowadzenia do obiegu kulturowego wartości, które kulturę rozsadzą i zniszczą.

Może właśnie w tym miejscu dochodzimy - symbolicznie, rzecz jasna - do punktu, w jakim rodzi się konserwatyzm Błońskieg ${ }^{50}$. Bo niewątpliwie zdawał sobie on sprawę $\mathrm{z}$ dwuznaczności eksperymentu: i jeśli wierzył w jego potencjał (a wierzył, przynajmniej na początku, niewątpliwie), jeśli był w stanie opowiedzieć się po stro-

J. Błoń s ki, Bezdroże. „Życie Literackie” 1967, nr 42, s. 13.

Warto tu wspomnieć o tym, jak widzi relacje między recenzjami Błońskiego dotyczącymi Doryckiego krużganku i Pierwszej świetności B. Ow c zar e k (O prozie Leopolda Buczkowskiego. Zmienić perspektywę. „Przegląd Filozoficzno-Literacki” nr 41〈2015〉). Zwraca on bowiem uwagę na to, że dochodzi w tych recenzjach do głosu swoisty tradycjonalizm krytyka, dostrzegalny w samym definiowaniu literatury. W tekstach Błońskiego - pokazuje badacz - mocno wyeksponowany zostaje problem c zy teln oś ci; Czarny potok i Dorycki krużganek można poskładać, lektura Pierwszej świetności musi zaś być oparta na założeniu o nieczytelności tej powieści. W świetle założeń Błońskiego - to zarzut. Jak jednak komentuje Owczarek: fakt, że ocena owa ma charakter negatywny, wynika z przeświadczenia, iż narracyjność jest esencjonalnym równoważnikiem literatury. Na pewne wymiary czyniło to piszącego nieczułym - „Błoński nie widział w prozie Buczkowskiego istotnej przemiany jej funkcji przedstawienia i nie dostrzegł zmiany w odnoszeniu literatury do literackiej konwencji, nie widział jej funkcji prezentacji i demonstracji chwytu czy ironii, czyli wielowymiarowego przedstawienia świata" (ibidem, s. 231). 
nie atrakcyjności transgresji, to zarazem od pierwszych chwil dostrzegał mocno wyznaczone granice: taka próba nie powinna stać się narzędziem dezintegracji. I gdy rozsadza porządek rzeczy, nic nie oferując w zamian - jest nie tylko bezwartościowa, ale i niebezpieczna: odtrąca od jedynego oparcia, jakie, być może, w ogóle współcześnie mamy. Stąd, jak sądzę, w krytyce Błońskiego aprobata wobec literackiego bluźnierstwa Francuzów i wyrażana tylko pośrednio złość na pisarzy, którzy - jak Buczkowski - chcieli być wyłącznie piewcami rozpadu, nie szukając dlań żadnego uzasadnienia. Jeżeli kultura nie będzie tęsknić za czymś większym od niej samej, co pozostanie? Jeżeli w chaosie nie będzie chciała odnaleźć choćby śladów dawnego porządku bądź zalażków nowego ładu, jak ma się w niej odnaleźć człowiek? Świat Buczkowskiego jest dla Błońskiego światem nie do pomyślenia - radykalnie obcym i odrzuconym. I we wszystkich wypowiedziach krytyka na ten temat dominuje lęk przed jednym: przed tym, że to autor Czarnego potoku mógłby mieć rację.

Niemal dekadę wcześniej - w szkicu o Genecie - Błoński stwierdzał:

Tak jak nigdy żaden pisarz nie napisze książki, która objęłaby całość rzeczywistości, tak nigdy nie uda się tej rzeczywistości całkowicie zniszczyć. Czy jednak oba te marzenia - pozytywne i negatywne - nie uzupełniają się wzajemnie, a nawet czy się przypadkiem nie utożsamiają?51

Myśl ta dobrze wyraża stanowisko twórcy Zmiany warty: szukał on takiego modelu kultury, w jakim energia anarchii spotykałaby się ze spokojem ładu; te dwie siły są bowiem u Błońskiego nierozerwalnie ze sobą powiązane - anarchia pozwala nam przeżyć i dostrzec ład na nowo, ład zabezpiecza przed inwazją i destrukcyjnością anarchii. Jak łatwo więc zrozumieć, żadna $\mathrm{z}$ owych mocy nie zdoła uzyskać przewagi - bluźnierstwo wydaje się atrakcyjne tylko wtedy, gdy jest przeciwko komu je kierować. Ono służy temu, by kultura raz jeszcze przypomniała sobie o swojej sakralności - biada jej jednak, gdy tę będzie chciała ostatecznie zanegować. Jak się wydaje, Błoński zgadzał się w owym punkcie z Czesławem Miłoszem: są takie prawdy, o których czytelnikowi nie należy mówić, nie wolno bowiem niszczyć jego nadziei.

Bodaj w 1986 roku krytyk pisał do Lema: „Witkacy, Gombro co noc mnie nawiedzają i męczą, szydząc, że im rady dać nie mogę. Ale jak dożyję, to jeszcze chyba zmogę, skromnie, ale zmogę" 52 . Jak wiemy - zmógł, ale tak jak literatura jest tylko marnym odblaskiem Książki z manifestu Błońskiego, tak i tomy poświęcone wymienionym autorom sa jedynie niewiernym odwzorowaniem Księi zamierzonej przez krytyka. Gdyby zrealizował on swoje plany z przełomu lat sześćdziesiątych i siedemdziesiątych XX wieku - a zaliczał do nich i opublikowanie monografii Witkacego (już, już kończonej!), i scalenie szkiców poświęconych dramatowi - otrzymalibyśmy prawdopodobnie pozycje bliższe wyrażonym tu intuicjom. Jak jednak wiadomo, najciekawsze są zawsze dzieła nienapisane i lubię czasem myśleć o tym tomie-apokryfie, Błońskiego wersji Ziemi Ulro, dużo bardziej drapieżnej od jego

51 Błoń s ki, „Balkon”, czyli zabójstwo Boga, s. 105.

52 J. Błoń s ki, list do S. Lema, z 30 XI [198?]. Archiwum S. Lema w Krakowie. 
późniejszych interpretacji. O takiej książce, w której przyglądają się sobie nawzajem Sęp Szarzyński i Cyprian Norwid; w której Witkacy o sztuce i jej znaczeniu dialoguje z Proustem; w której Błoński wyciąga i dopowiada wnioski z zestawienia Gombrowicza z Genetem; konsekwentniej rozpisuje refleksję nad Buczkowskim i nad Andrzejem Kuśniewiczem; zdaje sprawę z tego, skąd bierze się jego głębokie rozczarowanie Tadeuszem Różewiczem i opowiada się - tak! - za Miłoszem, bo przecież drugą stroną negatywizmu Błońskiego pozostaje już wtedy poszukiwanie epifanii ${ }^{53}$. Apokryf ten jednak - jakby roztrzaskany - można tylko rekonstruować z publikowanych fragmentów, rozrzuconych po czasopismach; scala dziś te teksty głównie namysł czytelnika, szukającego pierwotnego zamierzenia. Warto się na ten wysiłek zdobyć, bo niewykluczone, że jest to najważniejsza i najpiękniejsza z książek Jana Błońskiego.

\section{Abstract \\ MAŁGORZATA SZUMNA Jagiellonian University, Cracow \\ AMBIGUITY OF EXPERIMENT ON THE CATEGORY OF "REVERSED SACRUM" IN JAN BŁOŃSKI'S CRITICAL DISCOURSE}

The article attempts to reconstruct the significance of "reversed sacrum" category in Jan Błoński's critical discourse. The author polemicizes with the thesis according to which metaphysical subject matter was to have been openly clarified by the critic no sooner than in his 1985 volume Kilka myśli co nie nowe (Several Thoughts That Are Not New) and she shows the way it was problematized earlier, that is in his 1960s papers. Starting with the assumption that Błoński was predominantly interested in the $20^{\text {th }}$ century religiousness and its emergence in a distorted and parodic shape, often even mockery one, the author analyses his texts on Francophonic theatrical avant-garde (Michel de Ghelderode, Jean Genet, Antonin Artaud) and asks how the conclusions drawn from the books translated into his attempts to reflect on the Polish culture. Traps and perils connected with it are shown as based on the changeable interpretations of Leopold Buczkowski's creativity.

53 Proponowane tu zestawienie nie jest arbitralne, lecz stanowi odbicie tematyki esejów Błońskiego z tego czasu. W liście do A. Micińskiej z 10 V [1967] (archiwum A. Micińskiej. Bibl. Narodowa w Warszawie) J. Błońs ki pisał, dokumentując ten rozrzut obszarów zainteresowań: „Naprawdę jest tak, że maluczko, maluczko... a stanę oko w oko z naszym nieocenionym Witkacym; bo udało mi się zrzucić z siebie - to znaczy, w przeważającej mierze, wypełnić - prawie wszystkie zobowiązania smarownicze [...]. Utworzyłem setki nowych przypisów i uzupełnień do Sępa, napisałem o Pirandellu, Genecie, o poezji i tradycji, o młodej prozie, o pewnym mnichu z XVIII wieku, który napisał piękny wiersz nieznany, o Barthesie [właśc.: Barcie]; wygłosiłem także cztery odczyty, i jeszcze mam parę wygłosić, byłem w Kłodzku, Wrocławiu, Mielcu (!!), a zaraz jadę do W[arsza]wy i jeszcze potem do Lublina”. Poza tekstami, które zostały tu już przywołane, wspomnieć można m.in. o takich szkicach Błońskiego z tego czasu, które stanowiłyby dla omawianych zagadnień właściwy kontekst, jak: Powrót Witkacego. „Dialog” 1963, nr 9; Tertium datur. „Przegląd Kulturalny” 1963, nr 16 (głos w sprawie sensu czytania C. Norwida, S. Brzozowskiego i Witkacego); Moje narzekania. Ścieżki do nikad. Jw., 1963, nr 19 (o T. Różewiczu); Rozważania na czasie. „Dialog” 1967, nr 4; Norwid wśród prawnuków. „Twórczość” 1967, nr 5; Z Galicji do Koryntu. „Życie Literackie” 1967, nr 36 (o A. Kuśniewiczu); Bergson a program poetycki Leśmiana. „Miesięcznik Literacki” 1968, nr 8; U źródeł teatru Witkacego. „Dialog” 1970, nr 5; Witkiewicz ojciec i syn, czyli psychomachia rodzinna. „Twórczość” 1970, nr 7/8; Metafizyka i sobowtóry. „Nurt” 1971, nr 12; O problematyce dramatów Stanisława Ignacego Witkiewicza. Jw., 1972, nr 5. 